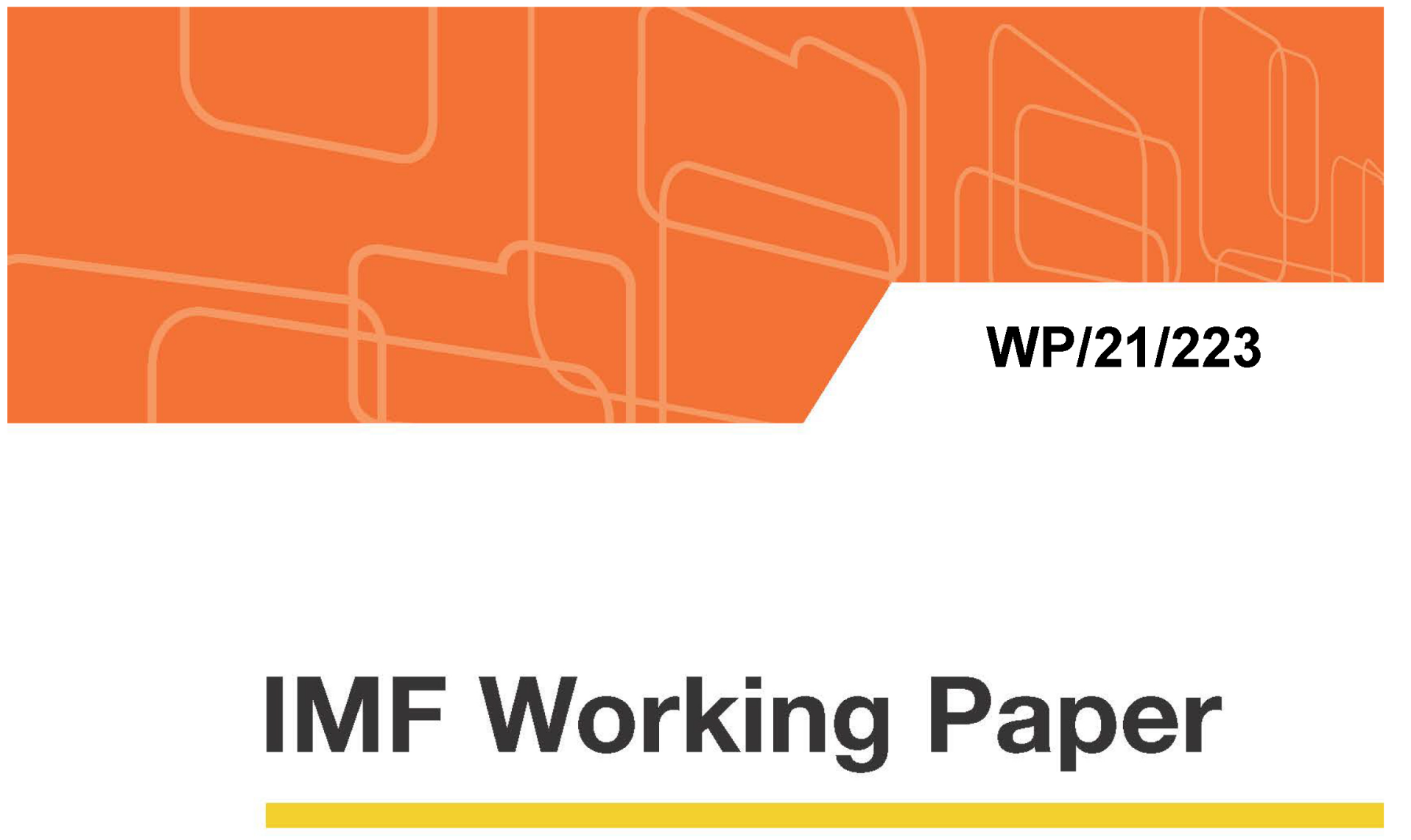

\title{
A Comprehensive Greenhouse Gas Mitigation Strategy for The Netherlands
}

by Nicoletta Batini, Simon Black, Oana Luca, and lan Parry

IMF Working Papers describe research in progress by the author(s) and are published to elicit comments and to encourage debate. The views expressed in IMF Working Papers are those of the author(s) and do not necessarily represent the views of the IMF, its Executive Board, or IMF management.

$$
\text { I N T E R N A T I O N A L M O N E T A R Y F U N D }
$$




\title{
IMF Working Paper
}

European Department

\section{A Comprehensive Greenhouse Gas Mitigation Strategy for The Netherlands}

\author{
Prepared by Nicoletta Batini, Simon Black, Oana Luca, and lan Parry ${ }^{1}$ \\ Authorized for distribution by Alfredo Cuevas
}

August 2021

\begin{abstract}
IMF Working Papers describe research in progress by the author(s) and are published to elicit comments and to encourage debate. The views expressed in IMF Working Papers are those of the author(s) and do not necessarily represent the views of the IMF, its Executive Board, or IMF management.
\end{abstract}

\section{Abstract}

The Netherlands has ambitious greenhouse gas emission reduction targets for the future - to cut them by 49 percent below 1990 levels by 2030 and 95 percent by 2050 . These targets and the likely new EU-wide targets under the recent EU Green Deal entail a rapid acceleration in decarbonization. This paper discusses the government's mitigation strategy and advances several recommendations to complement and reinforce that strategy and to achieve better alignement of the effective carbon prices across sectors. The paper discusses alternatives to make the recently-introduced industry carbon levy more effcient and recomends the use of revenue-neutral feebate schemes in industry, transportation, buildings, and agriculture. For power generation, it recommends eliminating taxes on residential and industrial electricity, supplementing the coal phaseout plan with an increase in the $\mathrm{CO} 2$ emissions floor price. The impacts of these reforms on consumption would be low and relatively evenly split across the income distribution.

JEL Classification Numbers: Q48, Q54, Q58, H23

Keywords: Climate change, Netherlands, climate mitigation, carbon pricing, feebate, revenue recycling, natural gas, industry, buildings, transportation, agriculture.

Author's E-Mail Addresses: Nbatini@imf.org; Sblack@imf.org; Oluca@imf.org IParry@imf.org.

\footnotetext{
1 The authors are grateful to the authorities, participants in the EUR seminar, and Alfredo Cuevas for very helpful comments and suggestions. All errors remain our own.
} 


\section{Introduction}

The Netherlands has reduced greenhouse gas (GHG) emissions by 17 percent relative to 1990 levels and has a national target to further cut emissions 49 percent below 1990 levels by 2030 . The national target was adopted in the 2019 Climate Agreement $^{2}$ but will need strengthening given the recently announced EU pledge to cut GHGs 55 percent below 1990 levels by 2030. To support the national goal, the Netherlands has adopted progressively tightening emissions targets for each of the main emissions producing sectors, namely industry, power generation, transportation, buildings, and agriculture. By 2030, the Netherlands also intends to phase out coal generation, boost the share of renewables in electricity production to about 70 percent, and increase the sales share of zero emission vehicles to 100 percent.

The Netherlands is implementing an extensive package of incentives and regulations to reduce emissions (on top of existing fuel taxes); to meet the country's ambitious climate goals, additional measures will still be needed, even before the prospective tightening of national and sectoral emissions targets. This paper proposes a package of fiscal policy measures designed to complement and reinforce existing measures and improve the overall efficiency of the mitigation strategy.

\section{The major recommendations include:}

- Modifying the carbon levy for the industrial sector by turning it into a revenue-neutral feebate. This reform would cost-effectively provide ongoing incentives for all firms to cut emissions, limit burdens on the average firm to better address competitiveness and leakage concerns, and automatically update with decreases in industry-wide emission rates.

- Progressively eliminate, in a revenue-neutral way, taxes on residential and industrial electricity use, replacing them with additional surcharges on $\mathrm{CO}_{2}$ emissions from power generation/district heating and on coal generation. This reform is sufficient (alongside other measures) to achieve the 2030 emissions target for this sector.

- Modify the vehicle excise tax system to include a pure feebate. This reform would efficiently strengthen incentives for switching to cleaner vehicles especially within the group of high efficiency internal combustion engine vehicles.

- Progressively raise the diesel tax to the level of the gasoline tax in the near term, and transition to $\mathrm{km}$-based charging in the longer term. The first reform would remove a distortion in the vehicle purchase decision (that is not warranted on environmental

\footnotetext{
2 GON (2019).
} 
grounds), while the second would stabilize revenues from the transportation sector while allowing far more efficient management of road traffic congestion.

- Apply feebates to the building sector to promote energy efficiency and clean technologies. Feebates could encourage energy-efficient appliances and electric heating systems and could be integrated into real estate taxes to reward buildings with higher energy performance.

- Apply feebates to the agriculture sector and use fiscal incentives to repurpose (mainly livestock) farms toward polyculture farming. Feebates could be charged on the difference between farmers' $\mathrm{CO}_{2}$ equivalent $\left(\mathrm{CO}_{2 \mathrm{e}}\right)$ emissions per hectare and the industry average, accounting for nitrous oxides, methane, as well as $\mathrm{CO}_{2}$. This reform could be complemented with measures to discourage consumption of emissions-intensive products including strengthened fiscal schemes that raise the relative price of beef, pork, and dairy products, and reinforced with structural reforms to increase the share of organic farming and reduce the stock of animals raised.

The paper is organized as follows. The next section provides background on emissions trends, emissions and clean energy targets, and existing policies at EU and domestic level. Section III evaluates currently envisioned policy reforms, and suggested complementary reforms, to scale up mitigation in the industrial, electricity, transportation, building, and agricultural sectors. It also discusses the incidence on households of mitigation policies for the energy sector. Section IV offers brief concluding remarks. 


\section{Emissions and Policy Background}

\section{A. Emissions Trends}

\section{At a global level, the COVID-19 economic crisis has not reduced the urgent need for clean energy transitions. Global $\mathrm{CO}_{2}$ emissions, along} with other GHGs, must be cut by 30-60 percent below baseline levels (i.e., levels with no new or tightening of existing, mitigation policies) projected in 2030 to stay on track with climate stabilization targets. Without these emissions reductions, the likelihood of meeting temperature stabilization goals will decline rapidly, especially if there is lock-in of long-lived fossil fuel capital over the next decade. Containing temperature rises to below $2^{\circ} \mathrm{C}$ requires phasing in measures (on top of existing measures) equivalent to a global carbon tax of around $\$ 75$ per tonne or more by 2030 (Figure 1) and rising further beyond 2030. The crisis has increased the urgency of carbon pricing in the sense that as economies recover, pricing provides the critical signal for ensuring new investment is appropriately allocated across clean energy and other sectors.

\section{By 2019 the Netherlands had reduced economywide GHGs 17 percent} relative to 1990 levels. Emissions from industry, buildings, and agriculture were lower by 35, 22, and 20 percent respectively, however power generation and transportation emissions were 7 and 9 percent higher (Table 1).

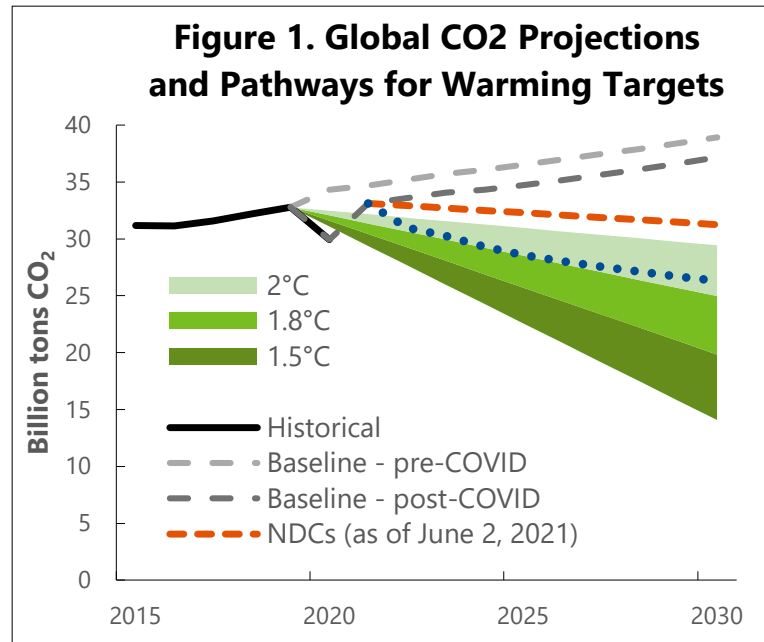

Source: Parry and others (2021). Note: Carbon tax starts at $\$ 15$ per ton, rising steadily thereafter from 2022 to 2030 . Warming pathways assume $\mathrm{CO}_{2}$ emissions are reduced in proportion to total GHGs.

\begin{tabular}{|c|c|c|c|c|c|c|}
\hline \multicolumn{7}{|c|}{$\begin{array}{l}\text { Table 1. Greenhouse gas emissions per sector } \\
\qquad\left(\mathrm{Mt} \mathrm{CO}_{2} \text { equivalents) }\right.\end{array}$} \\
\hline & 1990 & 2015 & 2018 & 2019 & $\begin{array}{r}2025 \\
\text { proj } \\
(\mathrm{PBL})\end{array}$ & $\begin{array}{r}2030 \\
\text { proj } \\
\text { (PBL) }\end{array}$ \\
\hline \multicolumn{7}{|l|}{ Economy-wide: } \\
\hline Total (excl. land use) & 221.6 & 195.8 & 188.2 & 183.9 & 168.7 & 146.6 \\
\hline Total (incl. land use) & 228.1 & 200.9 & 193.1 & 188.7 & 172.9 & 150.2 \\
\hline \multicolumn{7}{|l|}{ By sector: } \\
\hline Industry & 87.0 & 56.4 & 56.8 & 56.7 & 54.3 & 53.1 \\
\hline Power & 39.6 & 53.3 & 44.9 & 42.3 & 34.2 & 18.8 \\
\hline Buildings & 29.9 & 24.5 & 24.4 & 23.3 & 20.3 & 18.6 \\
\hline Mobility & 32.2 & 34.6 & 35.6 & 35.2 & 33.9 & 31.6 \\
\hline Agriculture & 32.9 & 27 & 26.5 & 26.4 & 26 & 24.5 \\
\hline Land use & 6.5 & 5.1 & 4.9 & 4.8 & 4.2 & 3.6 \\
\hline \multicolumn{7}{|l|}{ EU-ETS and non-ETS: } \\
\hline ETS sector & 80.4 & 94.1 & 87.4 & 83.7 & 75.3 & 59.4 \\
\hline Industry & & 40.6 & 41.7 & 41.3 & 40.7 & 40.3 \\
\hline Power & & 52.6 & 44.9 & 41.8 & 33.9 & 18.6 \\
\hline Buildings & & 0.4 & 0.4 & 0.4 & 0.3 & 0.2 \\
\hline Mobility & & 0.0 & 0.0 & 0.0 & 0.0 & 0.0 \\
\hline Agriculture & & 0.6 & 0.4 & 0.3 & 0.4 & 0.3 \\
\hline Non-ETS sectors & 134.3 & 101.8 & 100.8 & 100.2 & 93.4 & 87.2 \\
\hline Industry & & 15.9 & 15.1 & 15.4 & 13.6 & 12.7 \\
\hline Power & & 0.8 & 0.0 & 0.5 & 0.3 & 0.2 \\
\hline Buildings & & 24.1 & 24.0 & 23.0 & 20.0 & 18.4 \\
\hline Mobility & & 34.6 & 35.6 & 35.2 & 33.9 & 31.6 \\
\hline Agriculture & & 26.5 & 26.1 & 26.1 & 25.6 & 24.2 \\
\hline Land use & 6.5 & 5.1 & 4.9 & 4.8 & 4.2 & 3.6 \\
\hline$\%$ reduction vs. 1990 (excl. land use' & 0.0 & 11.6 & 15.1 & 17.0 & 23.9 & 33.8 \\
\hline
\end{tabular}




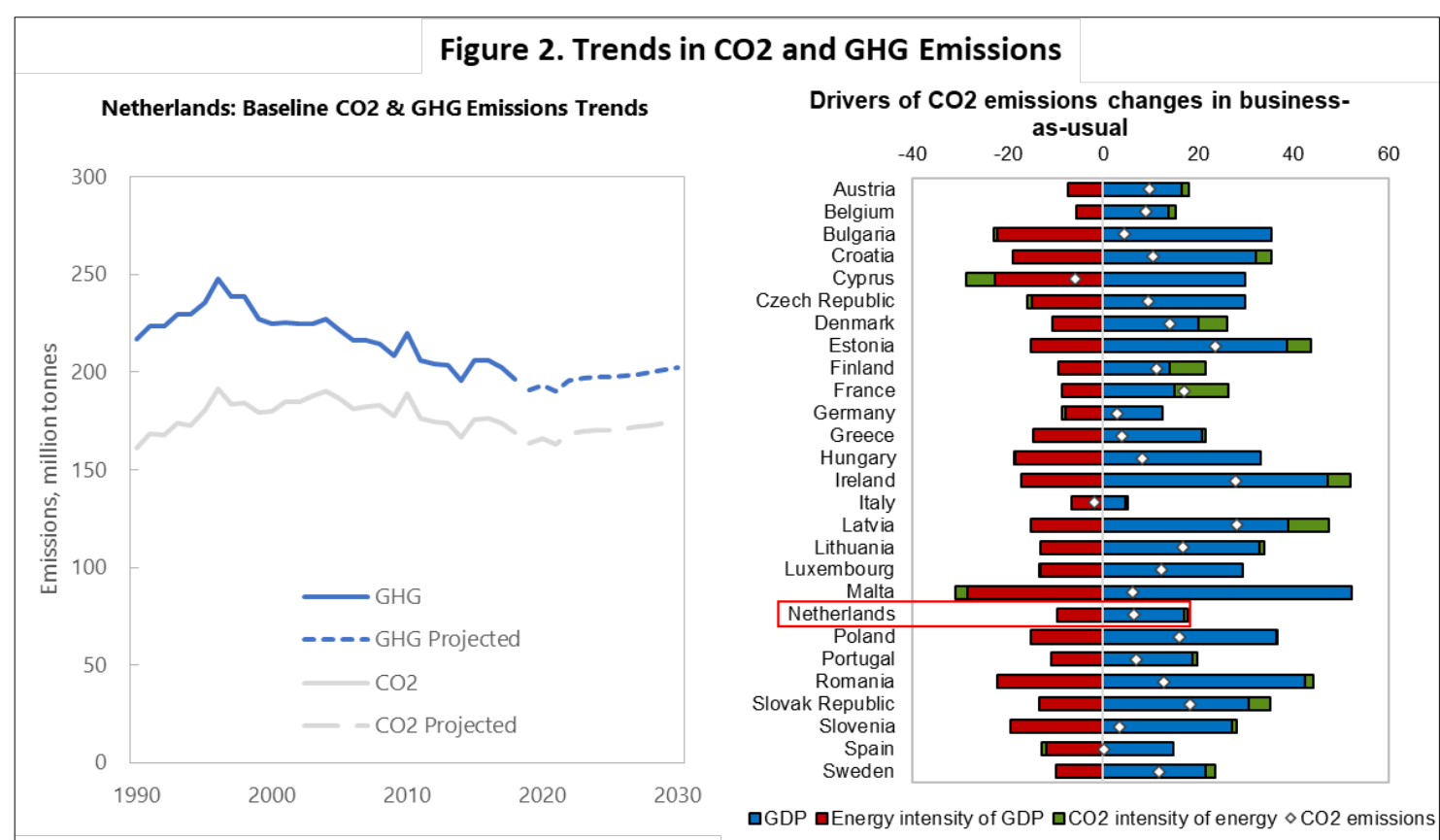

In a business as usual (BAU) baseline IMF staff project GHG emissions will rise $\mathbf{4 . 6}$ percent between

2020 and 2030. The BAU assumes no new or tightening of existing mitigation policies. ${ }^{3}$ Although GDP expands 11 percent over this period, the emissions intensity of GDP declines 10 percent, reflecting gradual improvements in energy efficiency (as older, less efficient capital is retired) and an assumption that the demand for fuels and electricity increase by less than in proportion to GDP. Similar trends apply in many other EU countries, though BAU emissions would increase in fast-growing, lower income states (Figure 2).

\section{In per capita terms, the Netherlands emits more} than the average of its European peers. In 2018, per capita GHG emissions in the Netherlands were 11 tonnes $\mathrm{CO}_{2}$, almost 30 percent more than for the average European citizen (Figure 3). Even when compared to countries with similar per capita income, Netherlands ranks on the high side-for example,

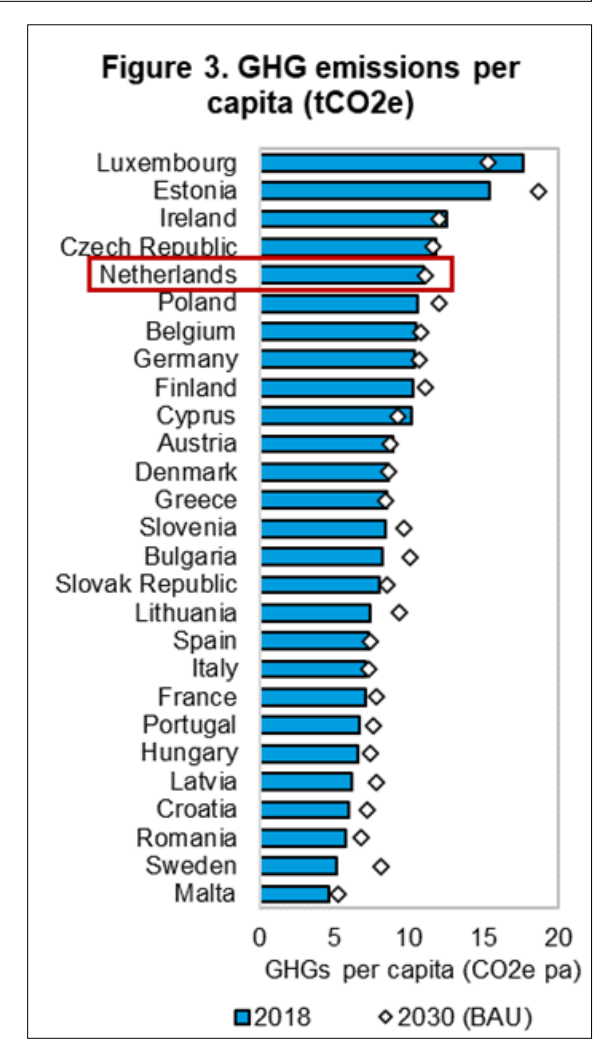

\footnotetext{
${ }^{3}$ That is, a baseline where fuel mixes are largely unchanged going forward and energy efficiency increases at historical rates. This baseline does not reflect a "current policy scenario" where regulations shift the energy mix during the period. For a detailed discussion, see IMF 2019b, Appendix III.
} 
GHGs in Austria, Denmark, France, Italy, Norway, Sweden, and UK were between 5 and 8 tonnes per capita. ${ }^{4}$

\section{Energy accounts for 81 percent of GHGs in the Netherlands. The power, industry, buildings, and transportation sectors account for 22, 29, 12 and 18 percent of GHGs respectively. Industrial processes (e.g., cement, chemicals) account for another 6 percent, agriculture 9 percent, land-use, land-use change and forestry (LULUCF) 3 percent, and waste (methane leaks from landfills) 1 percent (Figure 4 and Table 1).}

Figure 4. Composition of GHG emissions in Netherlands, 2018
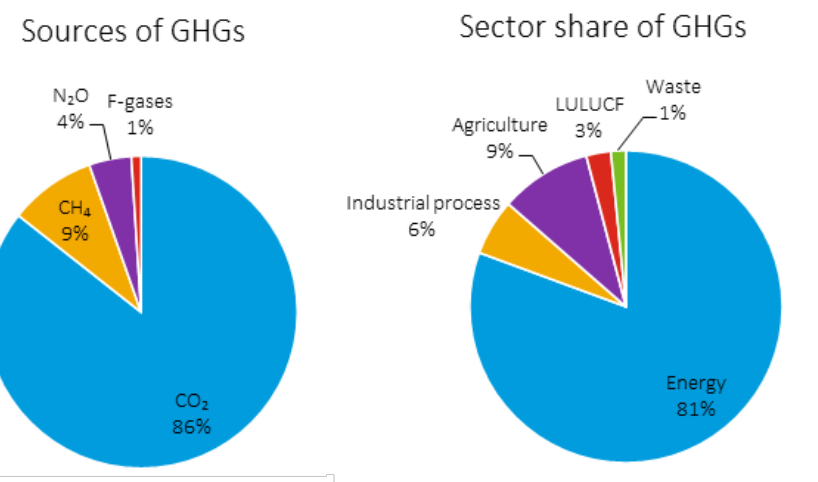

\section{B. Emissions and Clean Energy Targets}

For the 2015 Paris Agreement, the EU submitted a first-round Nationally Determined Contribution (NDC) pledging to cut EU emissions $\mathbf{4 0}$ percent below 1990 levels by 2030.

The EU-wide emissions reduction target does not automatically lead to a national target for the Netherlands. The EU has two distinct sectoral emissions targets:

- Emissions from power generation/district heating, large industrial firms, and within-EU aviation are covered by the EU Emissions Trading System (ETS) - these emissions are currently about 40 percent of EU GHGs. The first-round target was to cut these emissions 43 percent below 2005 levels by 2030.

- Emissions from transportation, buildings, small industrial firms, agriculture, and waste are covered by the Effort Sharing Regulation (ESR), which sets binding targets for these emissions to be implemented at the member state level. The first-round target was to cut these emissions 30 percent by 2030 relative to 2005 levels. Targets for ESR emissions are stricter for higher income states and the Netherlands target was to cut these emissions 36 percent by 2030 relative to 2005 levels or to 99.4 million tonnes (Mt) of $\mathrm{CO}_{2 \mathrm{e}}$ by 2030 relative to 2005 levels.

Given this context, the Netherlands' 2019 Climate Agreement proposed to reduce national GHGs 49 percent by 2030 relative to 1990 levels, with a further reduction of 95 percent by 2050 relative to 1990 levels envisaged under the Climate Law. The Climate Agreement

\footnotetext{
${ }^{4}$ Cross-country emissions comparisons however, which depend on economic structures and historical dependence on fossil fuels, are not a reliable indicator of mitigation efforts.
} 
includes indicative (non-binding) targets for the industry, power generation, buildings, transportation, and agriculture and land use to reduce emissions by a total of $48.7 \mathrm{Mt} \mathrm{CO}_{2 \mathrm{e}}$ by 2030 relative to baseline. ${ }^{5}$ In the Netherlands Environmental Assessment Agency (PBL)'s October 2020 baseline trajectory, emissions would be reduced by a total of $43 \mathrm{Mt} \mathrm{CO}_{2 e}$ relative to 2018 levels and $78 \mathrm{Mt} \mathrm{CO} 2$ relative to 1990 levels (Table 1).

The pace of emission reduction needs to double to achieve the $\mathbf{2 0 3 0}$ target. Under adopted and proposed policies, the emissions projected by PBL for 2030, excluding land use, amount to $147 \mathrm{Mt} \mathrm{CO} 2$ equivalents, or 34 percent, compared to 1990 levels (Table 1), leaving a significant gap to be addressed in the next decade (PBL at all, 2020). The largest emission reductions are envisaged in the power sector, more than halving by 2030 due to strong increases in renewable energy, low natural gas prices, phaseout of coal generation, and less use of natural gas generation. The PBL projections for the industry sector exclude the effects of the carbon levy, which at the time of the report was not sufficiently defined to be incorporated. Including the carbon levy introduced in January 2021 and a few other planned measures (which were excluded from the PBL projections), there is still an emissions shortfall of $14 \mathrm{Mt} \mathrm{CO}_{2}$ (Figure 5).

\section{Modifications to the Climate Act-both stronger emissions targets and measures-will be needed to comply with second-round commitments in the EU Green Deal announced in \\ September 2020. The enhanced} commitment is to cut EU GHGs 55 percent by 2030 relative to 1990 levels. More ambitious EU-wide targets for renewable energy and energy efficiency may also lead to higher contributions to these targets for the Netherlands. Concrete EU policy proposals to achieve the stricter EU targets are expected by mid-2021. IMF staff estimates suggest the new emissions
Figure 5. The Netherlands: Historical and Projected Emissions 1/ (Mt CO2 equivalents)

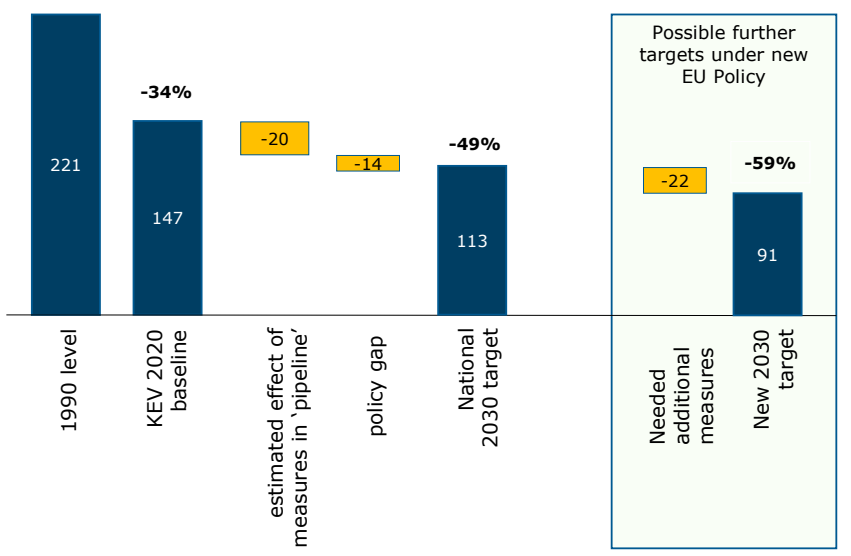

1/ Excludes land use

Source: Adapted from PBL 2020

${ }^{5}$ See https://www.klimaatakkoord.nl/organisatie/hoe-het-klimaatakkoord-tot-stand-kwam/sectortafels. 
targets would imply an additional emissions reduction commitment for the Netherlands of $22 \mathrm{Mt}$ $\mathrm{CO}_{2 \mathrm{e}}$ by $2030^{6}$. The Dutch government established a study group to consider the climate commitments resulting from the EU Green Deal and published a report in January $2021^{7}$ emphasizing the need for investments in clean technology infrastructure and critical technologies, and stronger regulations.

\section{Additional domestic targets at the sectoral level in the Climate Agreement include:}

- Transportation: Increasing the sales share of electric vehicles in new passenger vehicles to 100 percent by 2030;

- Buildings: Enhancing the energy efficiency of 1.5 million homes and 1 million utility buildings; and

- Electricity. Achieving an estimated 70 percent renewable share in electricity production by 2030.

\section{Current EU-Level Policies ${ }^{8}$}

The EU ETS limits the total amount of specified GHGs that can be emitted and allows participants to trade emission permits. The cap is currently scheduled to be reduced annually by 2.2. percent so that emissions will meet the first-round 2030 pledge for this sector-future caps will need tightening to meet the EU's second-round pledge. The ETS fixes the quantity of EU-wide emissions but leaves the price to clear the market. Where allowances are auctioned, revenues are channeled into national budgets largely based on the countries' historical emissions. The system ensures that the carbon price is equal in all participating countries and is economically efficient in that it incentivizes those firms with the lowest mitigation costs to act first. Within the Netherlands, the Dutch Emissions Authority (NEA) registers emissions for each plant and monitors whether the owner holds sufficient allowances for those emissions.

To address competitiveness and leakage concerns, energy-intensive, trade exposed (EITE) industries (e.g., iron and steel, aluminum, chemicals, refineries, cement) receive free allowances up to the level of the cleanest 10 percent of firms in the industry EU-wide. If a

\footnotetext{
${ }^{6}$ See the "National Greenhouse Gas Emissions Inventories and Implied National Mitigation (Nationally Determined Contributions) Targets" database available on the IMF Climate Change Dashboard at: https://climatedata.imf.org/datasets/72e94bc71f4441d29710a9bea4d35f1d_0/about. For EU countries, national targets include sectors covered by the EU ETS and the ESR. Reductions in both ETS and ESR sectors are assumed to increase in stringency to achieve the EU's new target (55 percent reduction on 1990 levels) at a similar level as that required to achieve the EU's previous target (40 percent reduction on 1990 levels).

7 See www.rijksoverheid.nl/binaries/rijksoverheid/documenten/rapporten/2021/01/29/bestemming-parijswegwijzer-voor-klimaatkeuzes-2030-2050/bijlage-1-rapport-bestemming-parijs-wegwijzer-voorklimaatkeuzes.pdf.

${ }^{8}$ See Chen and others (2020) for more detail on EU mitigation policies.
} 
firm is less efficient than the 10 percent of the best performing competitors, it must purchase additional emissions allowances for emissions exceeding the benchmark. Besides not covering all emissions (for most firms), free allowances do not compensate firms for mitigation costs. ${ }^{9}$ In July 2021, the European Commission proposed a transition away from free allowance allocations to a Carbon Border Adjustment Mechanism (CBAM) starting in 2023 (see below).

\section{Historically, ETS emissions prices have been volatile and generally low, though recently prices have become more robust (Figure 6). Prices collapsed} sharply in 2008 as the financial crisis led to a significant reduction in emissions, while the annual allowance volume was not adjusted. Prices have risen since 2018 following a European agreement to accelerate the reduction of emissions and the introduction of the Market Stability Reserve (MSR) in January 2019. The MSR puts a fraction of surplus allowances into a reserve when the surplus exceeds a certain threshold, to preempt the weakening of the carbon price signal. During the COVID-19 crisis, the ETS price initially dropped, but has since risen above $€ 50$ per tonne. With a fixed cap on emissions at the EU level, emissions reductions from overlapping policies in the Netherlands would be offset tonne-for-tonne by extra emissions in other EU countries (via a decline in the ETS allowance price). While the MSR is designed to offset to some degree this problem, a more robust and transparent mechanism would be to underpin the EU ETS with an exogenously set price floor, rising over time. ${ }^{10}$ Such mechanism would provide firms with more certainty over the future price path, allowing them to plan better for clean technology investment.

\footnotetext{
${ }^{9}$ Firms are compensated for charges on carbon embodied in electricity inputs through discounted electricity prices.

10 Price floors might be implemented through allowance auctions with a minimum auction price or making the MSR subject to a price trigger (see Flachsland and others 2018)-either way, allowances should be permanently withdrawn from the system whenever needed to prevent the price falling below the floor.
} 
The EU ETS is at the center of global momentum for carbon pricing. Over 60 regional, national, and sub-national carbon taxes and ETSs have now been implemented worldwide, though, at present, prices in most schemes are below about \$35 (€29) per tonne (Figure 7). However, Finland, Sweden, and Switzerland have carbon taxes (for their non-ETS sectors) of $€ 55$, $€ 112$ and $€ 87$ per tonne respectively, and Ireland plans to raise its carbon tax to $€ 80$ per tonne by 2030. Moreover, major pricing schemes have been introduced in China and Germany in 2021 and Canada has recently announced its price floor will rise to CAN \$170 (€114) per tonne by 2030 .

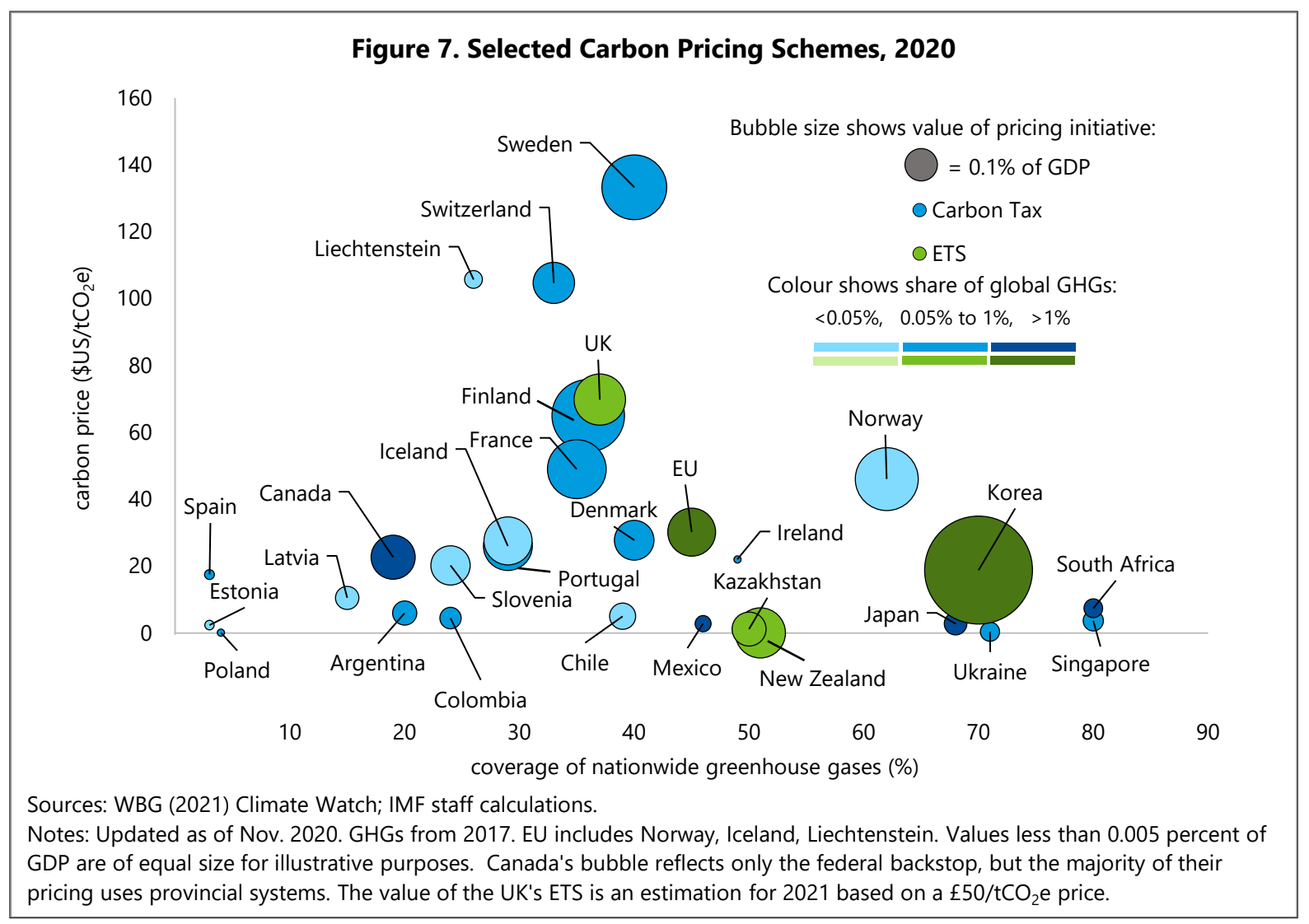

To achieve national ESR targets, member states can put in place country-specific polices such as carbon taxes, financial support, and regulations. The Commission is proposing to revise the ESR in view of the enhanced emissions targets for 2030 and has published an initial impact assessment and launched an open public consultation on the revision. The Commissions has also announced that it intends to propose extending ETS coverage to buildings and transportation.

Other EU directives target renewables, vehicle emission rates, energy consumption, and land use. These include: 
- A target for the EU across the block to increase the share of renewables in energy consumption to 20 percent by 2020 and to at least 32 percent by 2030;

- A target to reduce total energy use in the EU by 32.5 percent by 2030 compared with 1990;

- Standards for the fleetwide average $\mathrm{CO}_{2}$ emission rates of new passenger vehicles of $95 \mathrm{~g} \mathrm{CO}_{2} / \mathrm{km}$ in 2021 with a 37.5 percent reduction in 2030 compared to the 2021 standard; and

- $\quad$ Binding targets at the member state level for GHG emissions and removals from LULUCF.

\section{Current Domestic Policies in the Netherlands}

\section{Energy Taxation}

Fuel taxes are a key instrument for reducing emissions, particularly for the ESR sector.

According to OECD estimates (Table 2), gasoline and diesel excises were $€ 0.80$ and $€ 0.50$ per liter in 2018 . Although these taxes were largely introduced for other purposes (see below), they are equivalent to $\mathrm{CO}_{2}$ taxes of $€ 348$ and $€ 187$ per tonne respectively on gasoline and diesel. ${ }^{11}$ Natural gas for the building

Table 2. Effective Carbon Prices by Major Fuel Type in the Netherlands, 2018

\begin{tabular}{|lcc|}
\hline \multicolumn{1}{|c}{ Sector/fuel type } & $\begin{array}{c}\text { Share in } \mathrm{CO}_{2} \\
\text { emissions }\end{array}$ & $\begin{array}{c}\text { Fuel tax } \\
\text { expressed in } € \\
\text { per tonne of } \mathbf{C O}_{2}\end{array}$ \\
\hline Power/district heating & & \\
Coal/other solid fuels & 19 & 0 \\
Natural gas & 9 & 0 \\
Other fossil fuels & 4 & 0 \\
Industry & & 1 \\
Coal/other solid fuels & 4 & 19 \\
Natural gas & 15 & 0 \\
Other fossil fuels & 13 & 348 \\
Road transport & & 187 \\
Gasoline & 8 & 188 \\
Diesel & 11 & \\
Buildings & & \\
Natural gas & 16 & \\
\hline Source: OECD (2019). & \\
Note.Tax rates and emissions shares based on 2018 and \\
2016 data. Table excludes miscellaneous emissions \\
categories.
\end{tabular}
sector was taxed at $€ 188$ per tonne, and for industry at $€ 19$ per tonne. Other fossil fuels were subject to minimal or zero taxation.

\section{Gasoline taxes in the Netherlands are} higher than in other EU countries. When expressed in their implicit carbon tax equivalents, gasoline taxes vary between $€ 165$ and $€ 315$ per tonne of $\mathrm{CO}_{2}$ in other $\mathrm{EU}$ countries (Figure 8).

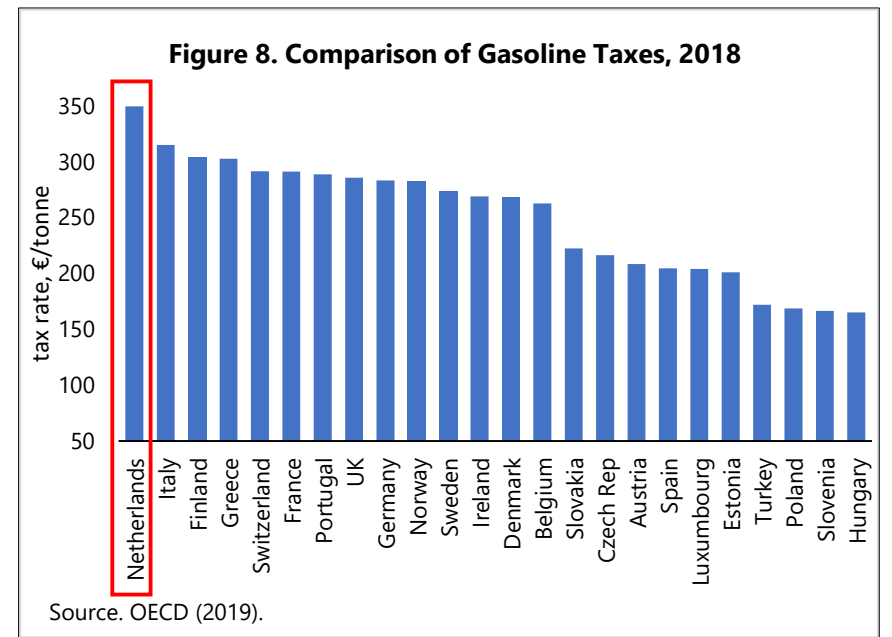

\footnotetext{
${ }^{11}$ A liter of gasoline and diesel produce 0.0023 and 0.0027 tonnes of $\mathrm{CO}_{2}$ respectively.
} 
Environmental costs approximately warrant the high gasoline tax in the Netherlands and an increase in the diesel tax. Retail gasoline prices for the Netherlands reflect supply costs, non-carbon environmental costs including local pollution and externalities from traffic congestion and accidents, as well as value added tax. However, diesel fuel prices fall well short of their efficient levels (before even pricing carbon) because excises undercharge for environmental costs. ${ }^{12}$ In general, fuel prices in other EU countries also either approximately reflect, or fall somewhat short, of their efficient levels (Figure 9). Fuel taxes however will gradually become less important over time with penetration of electric vehicles (EVs). The Climate Agreement proposes study of several options for a transition to charging vehicle use per $\mathrm{km}$ driven to maintain revenue and to enable finely tuned pricing of traffic congestion (see below). In the meantime, it is appropriate to reflect the full range of environmental costs in fuel taxes. ${ }^{13}$

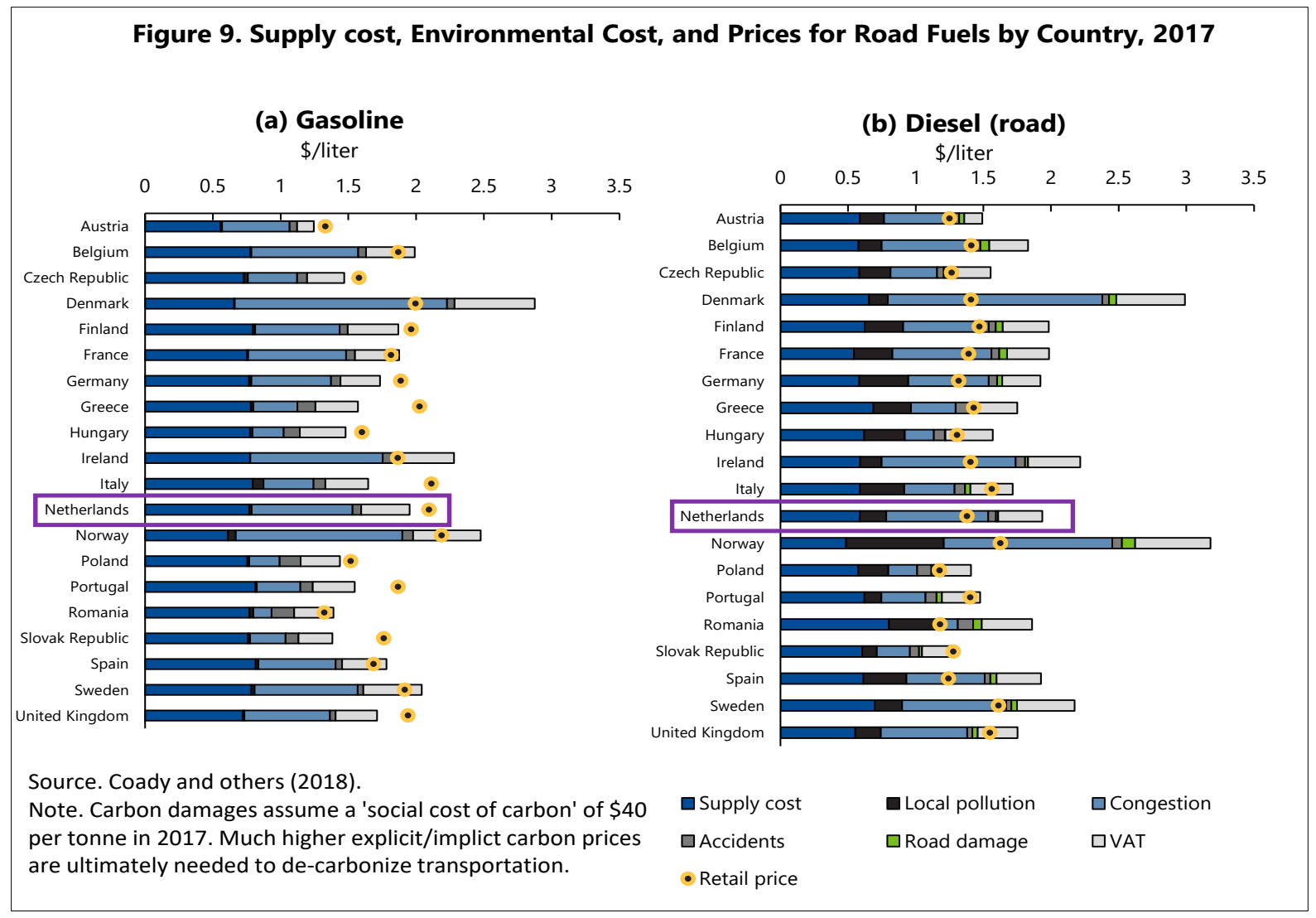

\footnotetext{
12 The composition of environmental costs differs between gasoline and diesel vehicles, but on net are moderately larger for diesel vehicles (e.g. the latter have higher carbon and local air emission rates). Estimates for diesel average over cars and heavy-duty vehicles.

13 See Parry and others (2014) for discussion of efficient fuel taxes (e.g., accounting for the bluntness of fuel taxes at addressing driving-related externalities) and methodologies for quantifying external costs by country.
} 
Taxes on residential natural gas use are dramatically higher in the Netherlands than they are in all but one other European country, (Figure 10). Local air pollution damages for natural gas are relatively small-they are more substantial for coal, though the relevance of this for the Netherlands is rapidly diminishing with the planned coal phaseout. ${ }^{14}$

\section{Taxes on electricity consumption in the} Netherlands are broadly in the middle compared with those in other European countries (see Figure 11). Taxes are $€ 22$ and $€ 32$ per megawatt-hour (MWH) for industry and households respectively. Some countries (e.g., Germany, Denmark) impose much higher taxes on household consumption, while in other countries (e.g., Czech Republic, Hungary, Ireland, Poland, Turkey, UK) taxes on both household and industrial consumption are small to zero.

Electricity taxes are a blunt instrument from a climate perspective however, as they only promote reductions in electricity demand and not reductions in the emissions intensity of power generation. They do not stimulate electrification of heating or of industry either.
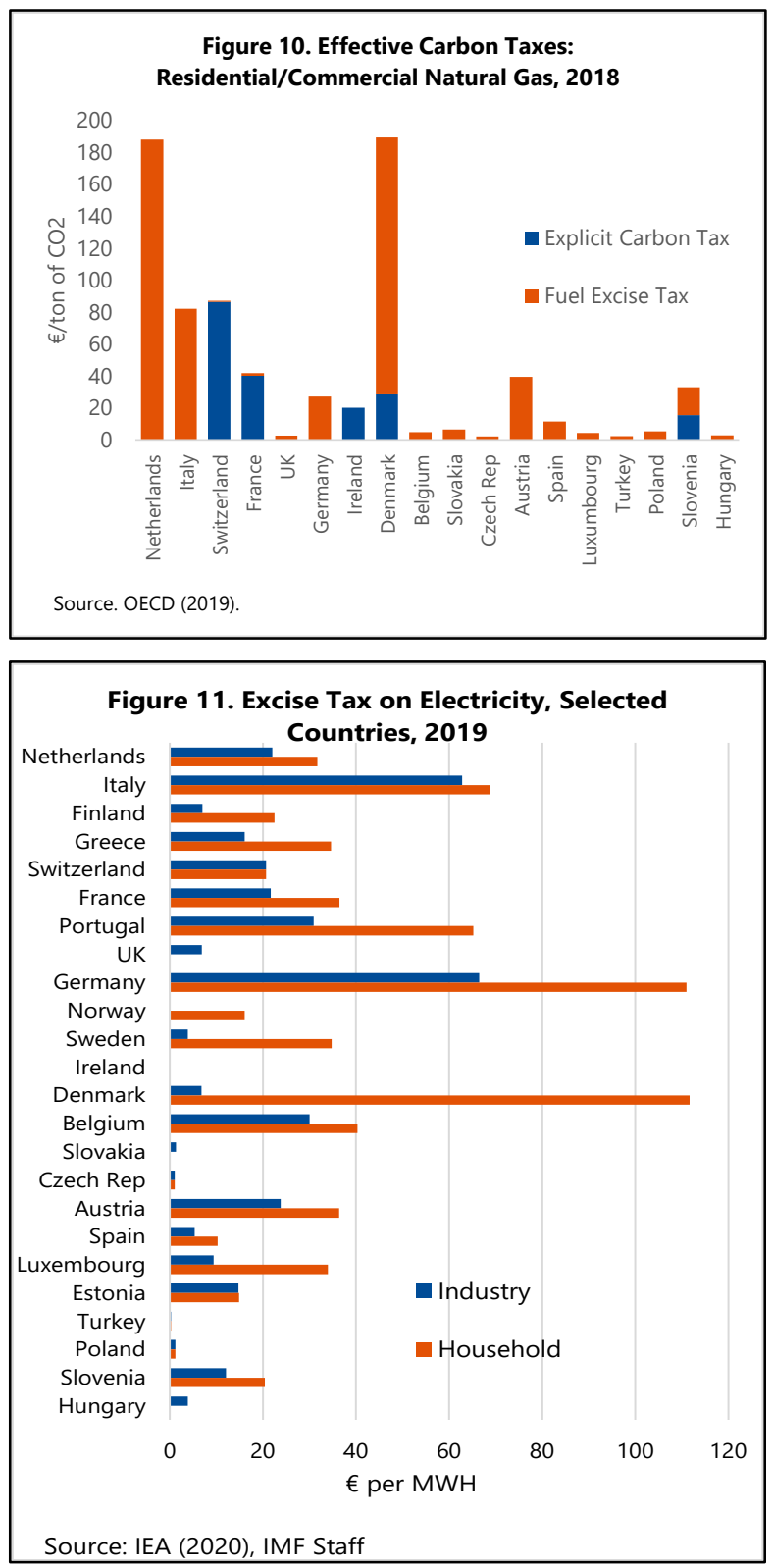

\footnotetext{
${ }^{14}$ Burning coal produces fine particulates, sulfur dioxide, and nitrous oxide where the latter two gases subsequently react to form particulates, while burning natural gas produces only the latter pollutant (and with lower emission rates than for coal) - fine particulates are respirable and elevate the risks of strokes and heart and lung diseases. Parry and others (2014) put local air pollution damages for coal at ten times damages for natural gas per unit of energy in the Netherlands.
} 
Vehicle taxes in the Netherlands rise sharply for vehicles with above average emission ratesmore so than in many other European countries (Figure 12). For year 2021, registration fees are between $€ 372$ and $€ 1,000$ for vehicles with emission rates below 95 grams $\mathrm{CO}_{2}$ per $\mathrm{km}$, and thereafter increase to $€ 7,100$ and $€ 23,500$ for vehicles with emissions rates of 150 and 200 grams $\mathrm{CO}_{2}$ per $\mathrm{km}$ respectively. Battery $\mathrm{EVs}$ also receive a subsidy of $€ 4,000^{15}$, which the Climate Act proposes extending to 2030. In 2020,

21 percent of newly registered cars in the Netherlands were battery EVs and another 4 percent plug-in EVs. ${ }^{16}$

\section{An expanded subsidy scheme is available to}

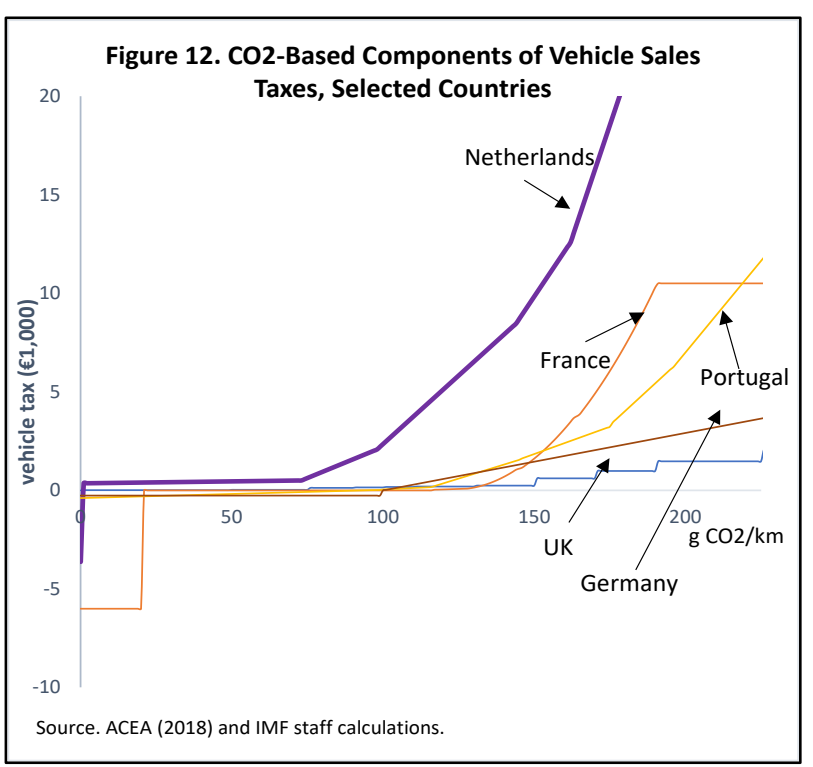

fund clean technology. Subsidy schemes are designed to fund operating shortfalls of renewable energy producers from charges collected on household and business energy consumers. Before 2020, the Netherlands operated a Renewable Energy Production Incentive Scheme (SDE+) paid for by a surcharge on energy consumption, or the Sustainable Energy and Climate Transition Storage (ODE). The SDE + was designed to compensate operating shortfalls for the generation of renewable energy regardless of the sector or type of investor. Starting 2020, the SDE + has been broadened to compensate GHG emissions reductions in other sectors, such as industry and agriculture, the built environment and transportation. ${ }^{17}$ Because it changes the focus from energy production to energy transition, the broadened subsidy scheme is called the Renewable Energy Transition Incentive Scheme (SDE++).

\section{An Evaluation of Fiscal Policy Options for Scaling up Domestic Mitigation}

The 2019 Climate Agreement envisages a combination of measures including a carbon levy for industry, tax reforms and price floors for the electricity sector, and subsidy schemes for renewable energy. The planned initiatives are summarized in Table 4. The discussion below first

\footnotetext{
${ }^{15}$ See https://zoek.officielebekendmakingen.nl/stcrt-2020-28162.html. Owners of battery EVs also benefit from waivers on registration fees and annual ownership taxes. In addition, 73 percent of new passenger EVs in the Netherlands were registered by companies in 2021 and employees receive favorable income tax treatment of this benefit in kind, which amounts to a further incentive of around $€ 200$ or more per month. See https://theicct.org/blog/staff/netherlands-ev-leader-feb2021.

${ }^{16}$ See https://theicct.org/publications/market-monitor-eu-jan2021. The Netherlands has the highest number of public charging points for EVs per square $\mathrm{km}$ in Europe. See www.eafo.eu/countries/netherlands/1746/infrastructure/electricity.

${ }^{17}$ For a description of the rates, see www.rijksoverheid.nl/onderwerpen/belastingplan/belastingwijzigingen-voorons-klimaat/energiebelasting-ode.
} 
provides general remarks on comprehensive mitigation strategies centered on carbon pricing, then discusses options for reinforcing fiscal policies taking each major emitting sector in turn.

\section{Comprehensive Mitigation Strategies}

Ideally carbon pricing should be the centerpiece of a country's mitigation strategies. Carbon pricing has several key attractions as it:

- Promotes the full range of opportunities for reducing energy use and shifting to cleaner energy sources across all covered sectors (by reflecting the cost of carbon emissions in the prices of fuels, electricity, and goods);

- Automatically minimizes the costs of these responses (by equalizing the cost of the last tonne reduced across fuels and sectors);

- Levels the playing field for clean technology investments (by establishing a robust price signal);

- Mobilizes a valuable source of revenue, including to plough back into the pursuit of climate objectives;

- Generates domestic environmental co-benefits (such as reductions in local air pollution deaths and

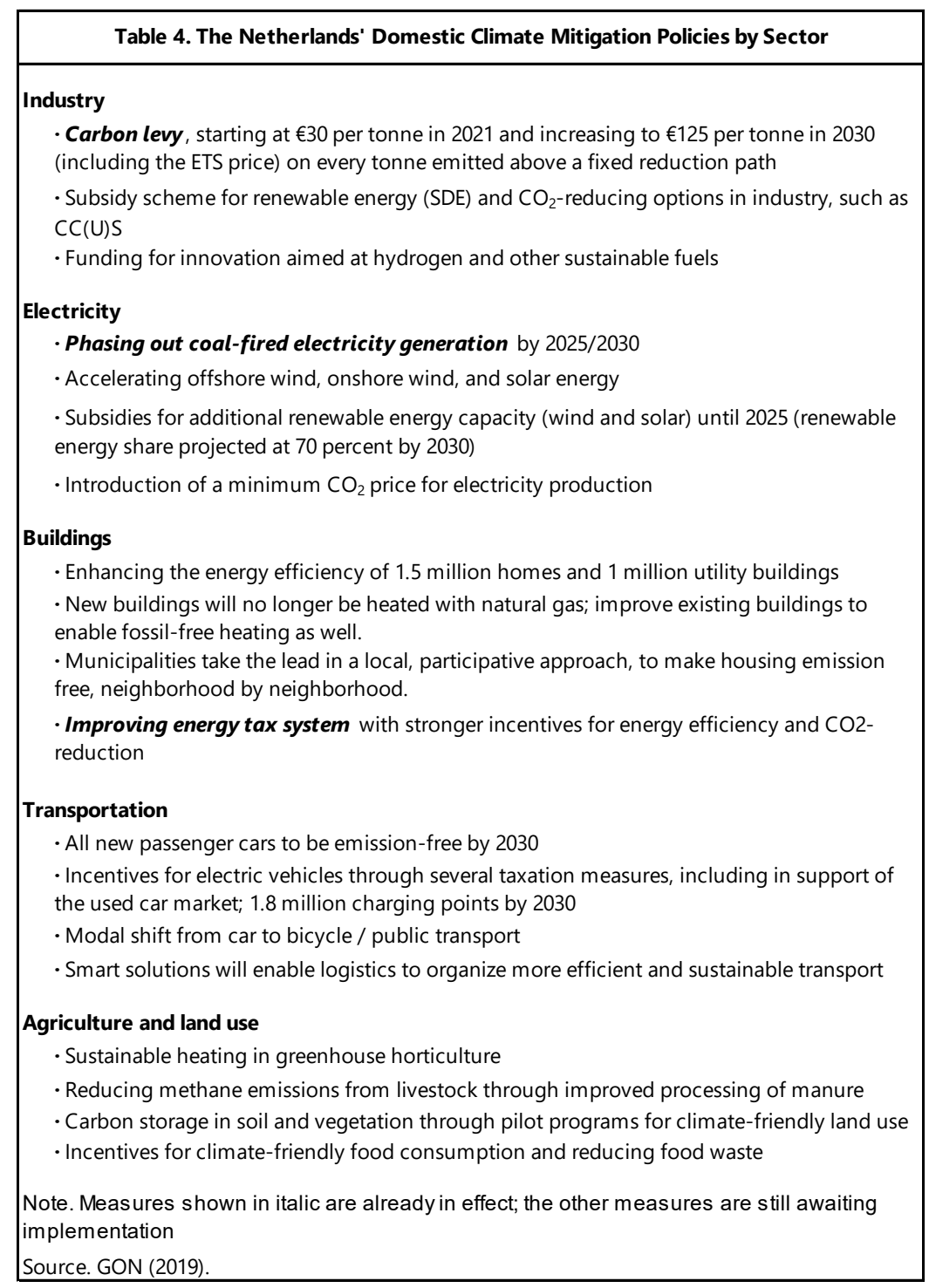
traffic congestion); and

- Is straightforward to scale up from an administrative perspective (building off capacity for the EU ETS and national fuel taxes).

Carbon pricing in the Netherlands is already comprehensive, and often with high prices by international standards, but: (i) prices will need to rise further; (ii) there is scope for better aligning prices across sectors; and (iii) more price certainty would create a better 
environment for investments in clean technology. Higher prices are needed given the difference between projected emissions and target emissions at the national and sectoral level as discussed in previous sections. Greater harmonization of carbon prices across sectors and fuels would lower the costs of a given reduction in nationwide emissions-in some cases though, notably road fuels, a significant amount of taxation is warranted by domestic environmental considerations, before applying charges for carbon emissions (see above). Emissions prices for the power sector, which are determined by the EU ETS, remain uncertain, and there is no automatic ramp-up for implicit carbon taxes for the building and transportation sectors.

\section{Some EU countries will likely require emissions reductions relative to BAU levels in 2030 that are comparable to, or in some cases are larger than, those needed in Netherlands}

(Figure 13). In part, this reflects the generally slower reductions in BAU emissions projections in most other countries noted above. Aside from coal intensive countries (e.g. Bulgaria, Czech Republic, Poland), the responsiveness of emissions to nationwide pricing (additional to any existing pricing schemes) is broadly comparable to that in the Netherlands. ${ }^{18}$

\section{Carbon pricing needs to be reinforced by other, less efficient but likely more} acceptable, measures at the sectoral level. Reinforcing measures are less efficient as they do not promote the full range of behavioral responses that are promoted by pricing instruments. ${ }^{19}$ One justification for sectoral measures is that uncertainties over the emissions impacts of carbon pricing increase at higher price levels. In this case, other measures can provide some 'insurance' if the emissions impacts of carbon pricing turn out to be smaller than projected. Another justification is that there are uncertainties surrounding the acceptability of higher carbon pricing due to its impacts on

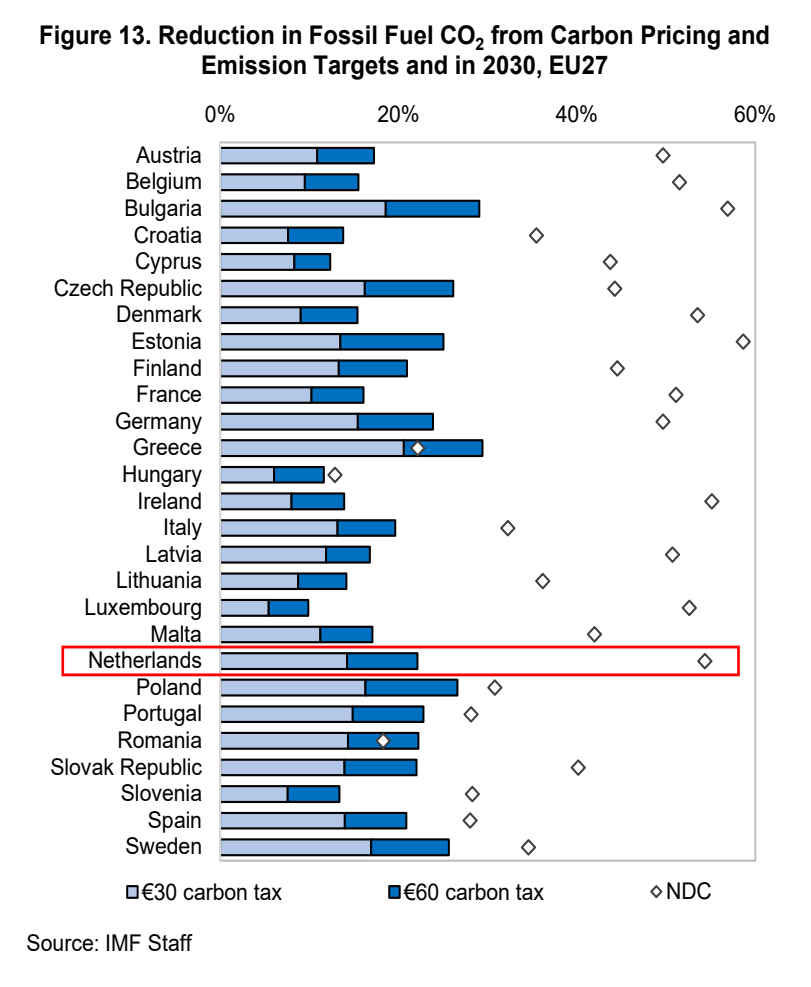

\footnotetext{
18 Unless otherwise noted, calculations below are based on an IMF tool which provides country level estimates of fuel use and emissions by major energy sector and estimates the effect of carbon pricing and other mitigation policies using assumptions about the price responsiveness of fuel use. See IMF (2019) for details.

${ }^{19}$ For example, vehicle taxes linked to emission rates and emission rate regulations progressively reduce the emissions intensity of the vehicle fleet. However, unlike higher fuel taxes, they do not encourage people to drive less.
} 
energy prices ${ }^{20}$. As such, reinforcing instruments that avoid a significant impact on energy prices may enhance the overall acceptability of the mitigation strategy.

The discussion below recommends considering an approach to enhance carbon pricing that makes ample use of feebates - revenue neutral tax-subsidy schemes, which are the fiscal analogue of regulations. Feebates would be applied by finance ministries, whereas regulations are the more natural instrument when climate policy is delegated to environmental ministries. Feebates can, in fact, be more flexible and cost effective than regulations-the latter generally require extensive credit trading provisions across firms and time whereas feebates, by design, generate efficiencies without the need for additional trading provision. And feebates can be implemented quickly with minimal administrative cost, at least in cases (e.g., transportation, power, industry, residential heating) where they would build off existing administration for taxes, subsidies, and operating the EU ETS.

\section{A variety of other supporting measures are needed to enhance the overall effectiveness and acceptability of a mitigation strategy with carbon pricing as its central element.}

Besides reinforcing sectoral instruments, the strategy should include public investment in clean technology networks, equitable and productive use of carbon pricing revenues, "just transition" measures to protect vulnerable groups and preserve industrial competitiveness, extensive stakeholder consultation and public communication, and pricing of broader emissions sources beyond fossil fuel emissions (Box 1).

\footnotetext{
20 For example, France's planned increase in its carbon tax was suspended in 2018 at $€ 45$ per tonne due to a public backlash against pricing.
} 
Box 1. Key Elements of a Comprehensive Mitigation Strategy

Supporting measures to enhance the effectiveness and acceptability of a mitigation strategy centered on carbon pricing include:

- A balance between pricing and reinforcing measures at the sectoral level that are less efficient but likely more acceptable;

- Public investment in the clean infrastructure networks that would not be adequately provided by the private sector (e.g., EV charging stations, transmission lines to accommodate renewables), as well as policies to advance critical technologies (e.g., electricity storage, green hydrogen);

- Recycling of carbon pricing revenues in

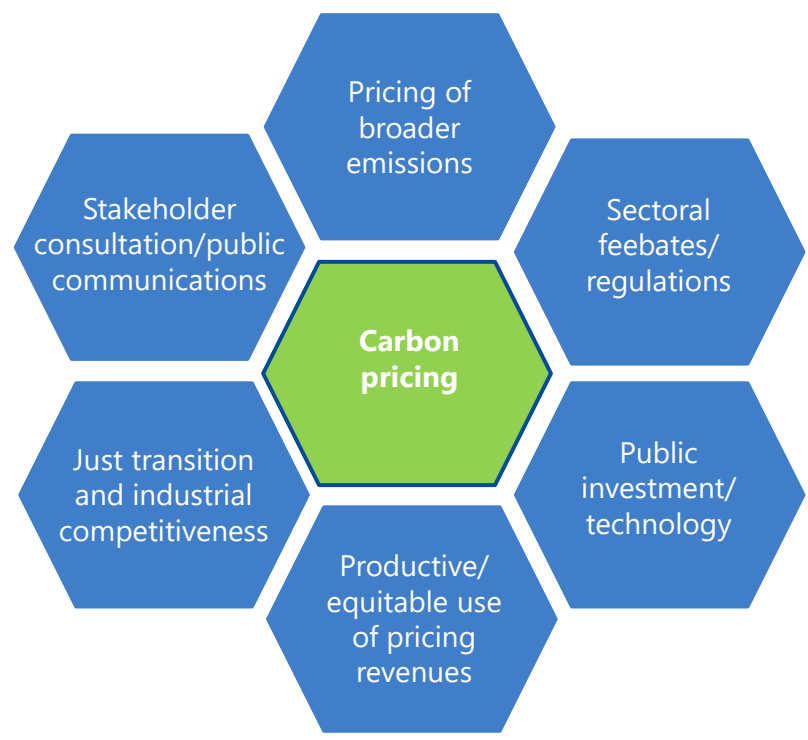
ways that boost the economy (e.g., through lowering taxes on work effort and investment or funding socially productive investments), making sure that benefits are equitably distributed across households;

- Just transition measures to assist vulnerable groups, such as stronger social safety nets or tax reliefs for low-income households, assistance programs for displaced workers and at-risk regions, and measures to limit the harm to industrial competitiveness;

- Extensive stakeholder consultation and public communication to build support for reform; and

- Measures (see below) aimed at broader sources of GHGs (e.g., agricultural emissions, methane leaks from natural gas extraction and distribution).

\section{Industry}

For the industrial sector, the key element of the Climate Agreement was the introduction in January 2021 of a levy on industrial $\mathrm{CO}_{2}$ emissions above a benchmark level, with the levy equal to any positive difference between an escalating target price and the prevailing EU ETS price. The trajectory of target prices is calculated to reduce projected emissions in line with the domestic 2030 target for industry emissions. The levy applies to large industrial companies that also fall under the EU ETS and to waste incineration plants and companies that emit large quantities of nitrous oxide. The target starts at $€ 30$ per excess tonne of $\mathrm{CO}_{2}$ emitted in 
2021 and rises in a straight line to $€ 125^{21}$ per excess tonne in 2030 . This would imply a levy of $€ 50$ per tonne for ETS installations, for example, if the EU ETS price were $€ 75$ in 2030 and of $€ 125$ per tonne for non-ETS installations such as waste plants. ${ }^{22}$ The base of the tax is firm emissions above the firm's "dispensation rights", which are calculated as:

production $\times \mathrm{CO}_{2}$ related to this production based on EU ETS benchmarks $\times$ reduction factor

where the EU ETS benchmark refers to the emission rate from the cleanest ten percent of firms in the industry at the EU-level and the reduction factor is set for 1.2 for 2021, declining to 0.69 by 2030. If a company emits less $\mathrm{CO}_{2}$ than allowed based on its dispensation rights, the unused dispensation rights can be carried back to the previous five years or sold to other firms subject to the levy. ${ }^{23}$ By itself, if binding the scheme cost-effectively promotes reductions in the emissions intensity of production for firms with emissions exceeding their dispensation rights. However, incentives for those with emissions below their dispensation rights to keep improving are harder to see without additional provisions.

\section{The carbon levy strikes a compromise between efficiency and leakage/competitiveness} concerns and is more practical administratively than other options. A pure carbon tax on all emissions would be more efficient in the sense that it would also reduce domestic emissions through reducing domestic production levels (as charges on remaining emissions are reflected in higher production costs), but at the risk of greater emissions leakage and a larger loss in competitiveness for domestic firms (as foreign producers are not subject to the same tax on their emissions). ${ }^{24}$ Most other countries have avoided pure carbon pricing of industry emissions ${ }^{25}$ through providing firms free allowance allocations (e.g., the EU and Korean ETSs), applying tradeable emission rate schemes (e.g., Canada), or exempting a portion of infra-marginal emissions from taxation (e.g., South Africa). Other possibilities (e.g., combining a pure domestic carbon tax with a domestic border carbon adjustment or output-based subsidies for industrial firms) imply greater administrative burdens than the Dutch levy.

\footnotetext{
${ }^{21}$ See https://carbonmarketwatch.org/2020/12/21/what-can-we-learn-from-the-dutch-national-carbon-tax.

22 The carbon levy shares some similarities with the UK Carbon Price Floor which imposed a national level variable tax (set three years in advance) equal to the difference between an exogenous target price and the projected EU ETS price-the system applied to power sector rather than industry emissions however. See Hirst (2018).

${ }^{23}$ Companies are required to submit an emissions and dispensation right calculation report to the Dutch Emissions Authorities who have responsibility for collecting the levy.

24 See Keen and others (2021) for further discussion.

25 Singapore is an exception.
} 


\section{However, a modest inefficiency of the carbon levy is that incentives for mitigation are truncated for clean firms, which could be rectified by converting the levy into a feebate.} Under the levy, firms have incentives to cut emissions to the EU benchmark but not necessarily to go beyond that. A modification of the levy is a feebate under which firms would pay a fee given by:

\section{$\mathrm{CO}_{2}$ price $\times\left\{\mathrm{CO}_{2} /\right.$ production - pivot point $\mathrm{CO}_{2} /$ production $\} \times$ production}

The $\mathrm{CO}_{2}$ price could be the same as currently envisioned for the levy, but the base of the feebate would reflect the difference between a firm's emission rate and a 'pivot point' emission ratefirms with emission rates above the pivot point would therefore pay taxes, while those with emission rate below the pivot point would receive subsidies. If the pivot point is set equal to the average emission rate for the domestic industry in the previous year, and updated annually, the feebate would be (approximately) revenue neutral over time. ${ }^{26}$ The feebate is slightly more effective than the levy as all firms face the same ongoing reward for cutting emissions by an extra tonne, regardless of whether they are currently paying fees or receiving subsidies.

\section{An EU-level carbon border adjustment would provide further re-assurances against competitiveness and} leakage concerns. Carbon emissions factors for EITE industries in the Netherlands are broadly comparable to those in other European and North American countries, but are well below those in China, Russia, and India (Figure 14). The EU plans to introduce a CBAM in 2023 (in the form of a requirement to purchase emissions certificates), and if this were related to countryspecific emissions factors the absolute cost increases would be far larger for industries in China, India, and Russia than

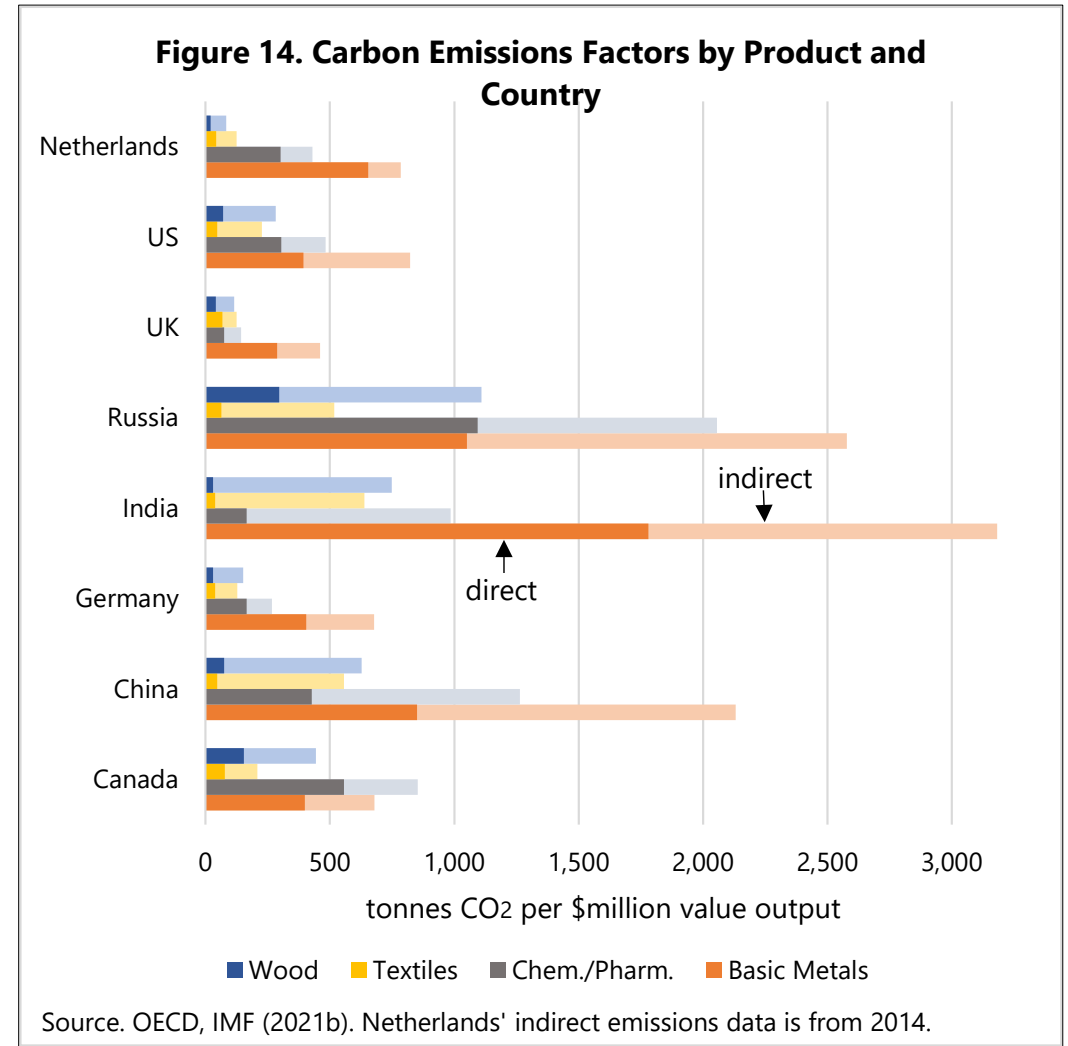

Source. OECD, IMF (2021b). Netherlands' indirect emissions data is from 2014.

\footnotetext{
26 In sectors dominated by one or a few firms (for example, steel), if an above-average polluter tries to decrease its emissions, the benchmark emissions also drop, which may erode incentives to reduce emissions (that is, such a firm would likely internalize its own impact on the benchmark). In this case, the pivot emission rate could be set exogenously and made progressively more stringent over time.
} 
Dutch industries. An alternative is to use EU emission rate benchmarks for all countries (to avoid relatively larger burdens on emerging market economies) and this would still provide some reassurance about the competitiveness of Dutch industries (at least relative to emerging market economies), despite the aggressively rising carbon levy.

\section{Power sector}

Currently, Netherlands' targets for its power sector are to cut emissions to $20.2 \mathrm{Mt} \mathrm{CO}_{2}$ in 2030 from $49.8 \mathrm{Mt} \mathrm{CO}_{2}$ in $\mathbf{2 0 1 8}$, a reduction of $\mathbf{5 9 . 4}$ percent. There are two technology-based targets to support this emissions objective. First, the Netherlands has enshrined in law the full phaseout of coal by 2030. Coal-based electricity generation has about double the $\mathrm{CO}_{2}$ emissions of natural gas, and although coal is a smaller portion of generation (30 percent compared with 58 percent for natural gas), it accounts for about the same $\mathrm{CO}_{2}$ emissions ( $25 \mathrm{Mt} \mathrm{CO}_{2}$ ). Second, the Netherlands intends to increase the share of renewables to 70 percent by 2030 (from about 11 percent in 2018), reducing the role of natural gas in power generation, which although cleaner than coal, is still not the preferred approach for most generation in the medium term. To support these technology and emissions objectives, two fiscal reforms are planned: a tax shift from electricity to natural gas and an EU ETS permit price floor (equivalent to a $\mathrm{CO}_{2}$ tax).

The major fiscal reform for the electricity generation sector proposed in the Climate Agreement is a shift in taxation away from electricity consumption and onto natural gasbased generation. The increase in tax rates for natural gas and reduction in rates for electricity was part of the 2020 law on fiscal measures of the climate agreement. The tax rate of natural gas increased by 4 cents per cubic meter in 2020 and +1 cent per cubic meter in the following 6 years. The funds will be used to offset the cost of the tax reduction and of a lower energy tax rate for the first bracket for electricity-households will benefit more from this change than businesses. A review is scheduled for 2023 to examine whether the proposed increase in natural gas tax is still necessary to maintain the desired sustainability incentives, in view of the market developments.

\section{Additionally, in January 2020 the Netherlands introduced a legislative proposal (not yet adopted) for a minimum price for $\mathrm{CO}_{2}$ emissions from power generation. The minimum price is proposed at $€ 12.3$ per tonne in 2020, increasing to $€ 31.9$ in 2030 , and is linked to the EU ETS. Should the EU ETS price fall below this minimum price, the difference will be levied in the form of a national-level carbon tax. The minimum carbon price is however far from binding at current ETS prices (see above).}

The shift from taxing electricity to taxing natural gas is an improvement from the perspective of efficiently reducing emissions. This is because taxing fuel inputs rather electricity output promotes both reductions in the emissions intensity of generation and reductions in electricity demand-taxes on electricity consumption promote only the latter response. Additionally, given the low share of other fuels in generation (oil accounts for 1.1 percent of 2018 generation) and the planned coal phaseout, the natural gas tax acts like a carbon tax in increasing the costs of non-renewable compared with renewable generation. 
The two fiscal reforms are unlikely to achieve the emissions reductions goals for Netherlands' power sector, however (Figure 15). Assuming a linear early retirement of existing coal capacity between 2022-30 (at this stage, there is no official timeline for the phaseout), the coal phaseout will make a large contribution to the reduction in $\mathrm{CO}_{2}$ emissions, from $50.9 \mathrm{Mt} \mathrm{CO}_{2}$ in 2030 in the baseline to $28.2 \mathrm{Mt} \mathrm{CO}_{2}$ (scenario 1). The shift from taxing electricity to taxing natural gas emissions would make a modest further contribution, cutting emissions by an additional $1.8 \mathrm{Mt} \mathrm{CO}_{2}$ to 24.6 (scenario 2), but emissions would still exceed the target of $20.2 \mathrm{Mt}$ $\mathrm{CO}_{2}$.

The authorities could therefore consider additionally increasing the price floor of the $\mathrm{CO}_{2}$ tax to $€ \mathbf{1 6 0}$ per tonne by $\mathbf{2 0 3 0}$. This would fully close the gap between planned policies and the target by 2030, while saving a cumulative $32.1 \mathrm{Mt} \mathrm{CO} 2$ between 2022 and 2030. However, it would still not achieve the target of 70 percent of a share of renewables in power generation by 2030, reaching 65 percent in 2035. ${ }^{27}$ To achieve this target, the government will need to adopt more demand-pull and cost-push policies such as feed-in tariffs which may help accelerate the adoption of solar and wind (Figure 15, right). Additionally, it may need to impose a new and politically challenging increase in electricity prices that would be passed forward to electricity users.

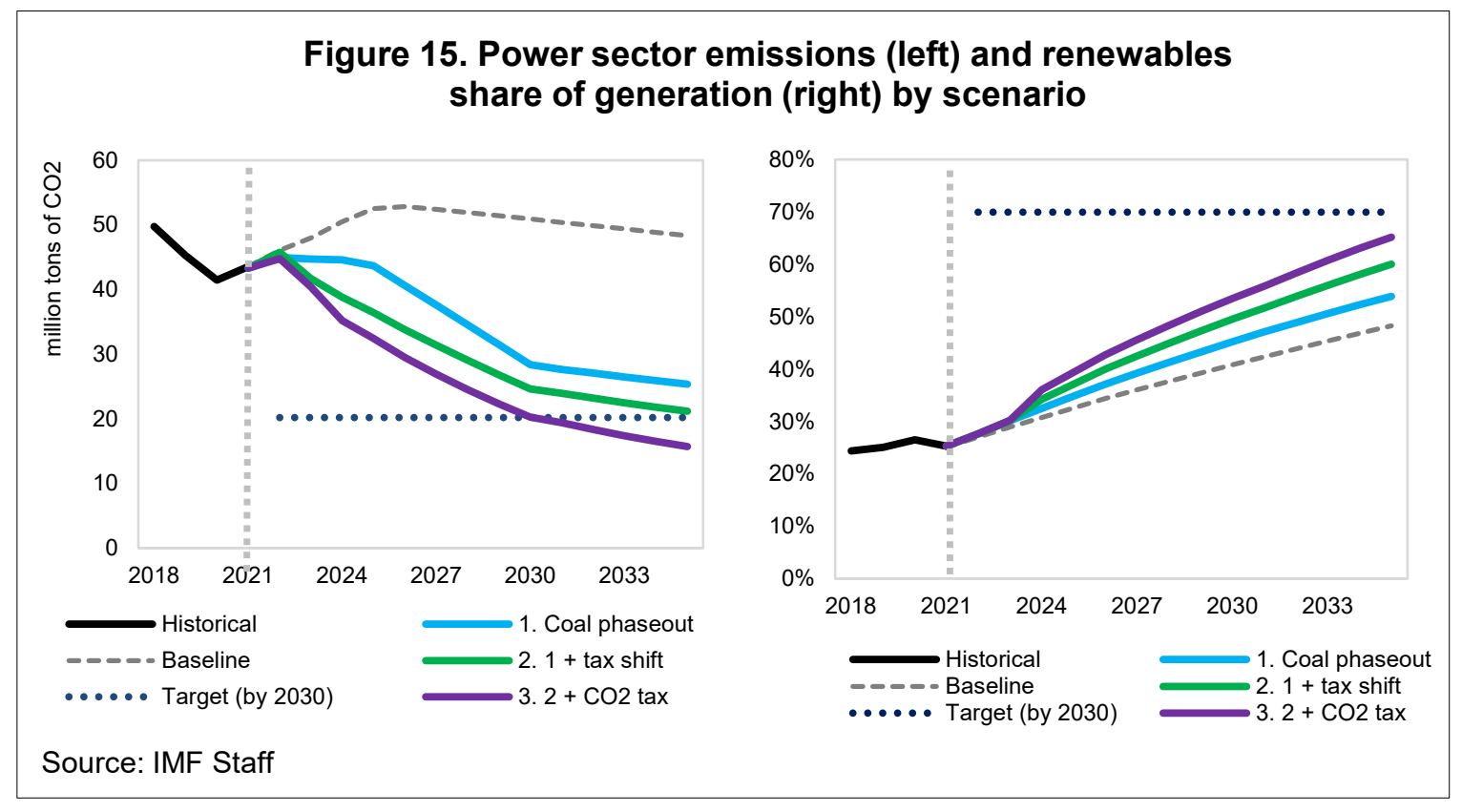

${ }^{27}$ Assumes that nuclear is considered a renewable source of electricity. 
The impacts of these reforms on consumers would be low and rather even across different income groups. ${ }^{28}$ The coal phaseout and tax shift would increase electricity prices by about 8.2 percent by 2030, since the early retirement of coal assets forces a shift in generation to higher cost sources, notably natural gas and new solar and wind. The impact on household consumption would be about 0.4 percent for the poorest quintiles and 0.3 percent of current consumption for wealthiest quintiles (Figure 16, left). This plus the additional $\mathrm{CO}_{2}$ tax on the power sector would raise prices by an additional 24.6 percent. This would increase the impact to about 1.4 percent for all quintiles, though the effect remains low (Figure 16, right). These calculations exclude effects of any additional policies needed to increase the share of renewables to 70 percent mentioned in the previous

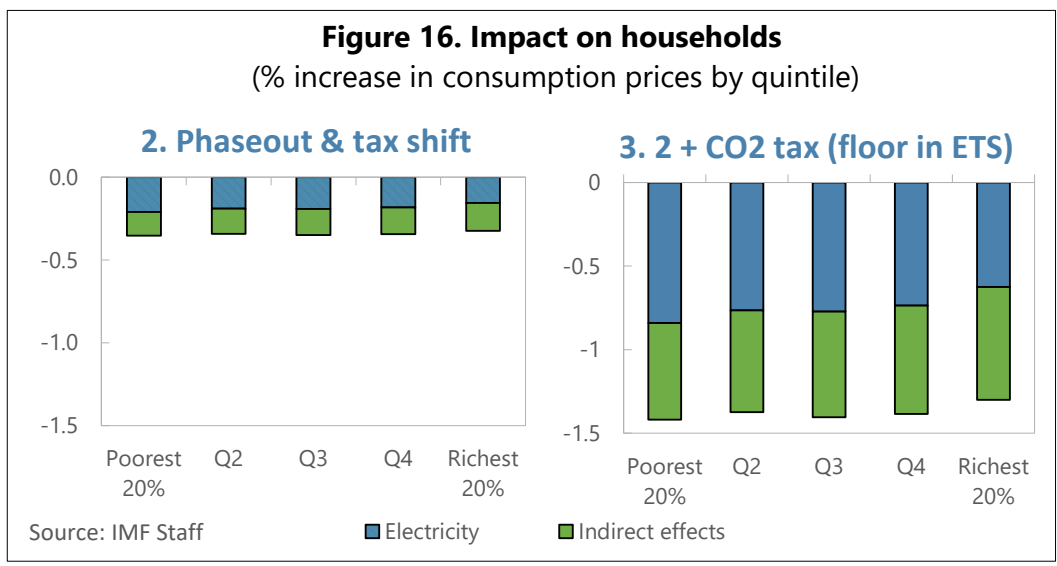
paragraph.

\section{Transportation}

The Netherlands' vehicle tax system provides strong penalties for purchasing internal combustion engine (ICE) vehicles with above average emission rates, but among ICEs with below average emission rates there are limited incentives to choose cleaner (non-EV) vehicles. For ICEs, the vehicle tax schedule is flat up to the current new vehicle fleetwide average emission rate.

The effectiveness and efficiency of the vehicle tax system could be refined by converting the registration fee schedule into a pure feebate system. Again, the feebate would provide a sliding scale of fees on vehicles with emission rates above a pivot point level and a sliding scale of rebates for vehicles with below average emission rates (including highly efficient petrol and diesel cars). Specifically, under a revenue neutral feebate (with pivot point equal to the fleetwide average emission rate) new vehicles would be subject to a fee given by:

$$
\begin{gathered}
\left.\left\{\mathrm{CO}_{2} \text { price }\right\} \times \text { the vehicle's } \mathrm{CO}_{2} / \mathrm{km} \text { - the sales fleet average } \mathrm{CO}_{2} / \mathrm{km}\right\} \\
\times \text { the average lifetime vehicle use (in discounted } \mathrm{km})\}
\end{gathered}
$$

Feebates have some attractions over the current registration fee system:

\footnotetext{
28 The analysis here is based on aggregate household budget data. For a more granular analysis, the detailed household budget survey, which could not be made available to the authors, would be necessary.
} 
- $\quad$ They sharpen incentives for lower emission vehicles (though mostly just within more efficient ICE vehicles) because the tax difference between any two vehicles is always proportional to the difference in their $\mathrm{CO}_{2}$ emission rates;

- $\quad$ They provide more certainty over government revenue from the vehicle tax system (unlike under the current system where revenues vary with the composition of vehicle sales). In this sense, the feebate component can be kept revenue neutral by annually updating the pivot point according the previous year's fleetwide average $\mathrm{CO}_{2} / \mathrm{km}$, while current revenues from vehicle taxes can be maintained through a uniform registration fee applied to all vehicles (including EVs);

- $\quad$ They do not require new data or administrative capacity relative to the existing registration fee system (just a recalibration of tax rates); and

- $\quad$ The $\mathrm{CO}_{2}$ price in the feebate can be adjusted annually if targets for EV penetration are not being met.

\section{For illustration, a feebate with a price of $€ 800$ per tonne of $\mathrm{CO}_{2}$ combined with a uniform registration fee of $€ 2,000$ per vehicle would increase the current net subsidy for EVs while maintaining revenue and providing strong incentives to shift from average to low emission rate ICEs (Figure 17). The lump-sum tax on all vehicles can be set equal to the average tax collected per vehicle under the current system to maintain revenue. The $\mathrm{CO}_{2}$ price in the feebate then determines the slope of the tax schedule - at current average vehicle emission rates a} feebate with $\mathrm{CO}_{2}$ price of $€ 800$ provides an incentive of $€ 2,800$ to purchase a car with $50 \mathrm{~g}$ $\mathrm{CO}_{2} / \mathrm{km}$ instead of one with $85 \mathrm{~g} \mathrm{CO}_{2} / \mathrm{km}$ (at present the incentive is €35). The penalties on high emission vehicles could be increased by adding surcharges to the feebate though (as under the current system) this would lead to some loss of efficiency due to different charges per tonne of $\mathrm{CO}_{2}$ on different vehicles. Subsidies for EVs (and clean ICEs) would decline over time as the average fleet emission rate declines, which is appropriate as the cost differential between EVs and their gasoline/diesel counterparts falls over time (e.g., with improvements in EV battery technology). For example, the upper feebate curve in Figure 17 shows the tax schedule for a fleetwide average of

Figure 17. Vehicle Tax Schedules under Feebates

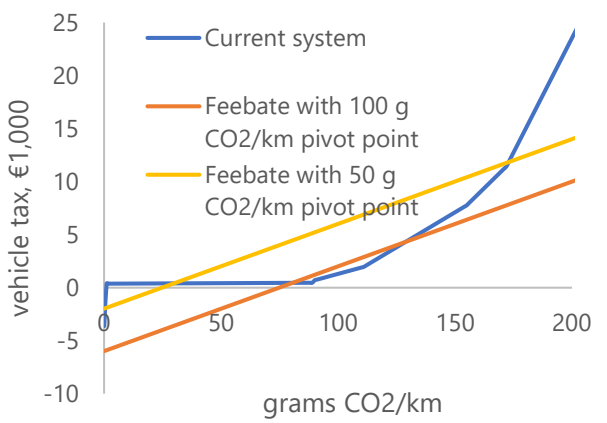

Note. Feebates assume a $\mathrm{CO} 2$ price of $€ 800$ and include a lump-sum tax of $€ 2,000$ per vehicle. Source: IMF Staff $50 \mathrm{~g} \mathrm{CO}_{2} / \mathrm{km}$. 


\begin{abstract}
A feebate that progressively shifted new sales to 100 percent EVs by 2030 would reduce road fuel emissions about $\mathbf{4 0}$ percent $^{29}$ below otherwise projected levels for 2030 . Deeper reductions would continue after 2030 as the fleet continued to turn over. ${ }^{30}$
\end{abstract}

\title{
A complementary reform would be to remove the favorable tax treatment of diesel fuel which would improve economic efficiency and generate, albeit moderate and transitional, emissions and fiscal benefits. Although diesel vehicles have higher fuel efficiency than their gasoline counterparts, per unit of fuel use diesel vehicles emit about 16 percent more $\mathrm{CO}_{2}$ emissions and estimated air pollution deaths from diesel fuel combustion are higher than for gasoline consumption. ${ }^{31}$ Raising the road diesel tax by $€ 0.30$ per liter (to increase it to the level of gasoline tax) would increase current pump prices for diesel by 34 percent and reduce diesel fuel consumption about 14 percent, $^{32}$ or $2 \mathrm{Mt} \mathrm{CO}_{2 \mathrm{e}}$, while raising revenues of 0.2 percent of GDP and removing the bias against gasoline vehicles. ${ }^{33}$
}

\section{Broader reforms using other fiscal instruments could address other transportation} externalities while maintaining government revenue. One key reform would be to introduce charges on passenger vehicle use related to $\mathrm{km}$ driven that vary with the prevailing degree of road congestion (i.e., charges per km would be higher for driving in congested conditions than non-congested conditions). This approach, which the authorities are considering, ${ }^{34}$ would more efficiently manage road congestion while enabling a transition to a robust funding source as the base of fuel taxes is progressively eroded. A second reform, which directly addresses road traffic accidents, is promoting a market-driven transition to pay-as-you-drive automobile insurance. See Annex 1 for more discussion of these reforms.

\footnotetext{
${ }^{29}$ This calculation assumes 8 percent of the fleet is replaced each year (i.e., vehicle lifespans are 12 years) and initially 20 percent of new vehicle sales are EVs, rising linearly to 100 percent by 2030 . Any impact on the overall size of the vehicle fleet should be small as the reform does not affect the price of the average vehicle. Vehicles might be driven more intensively as fuel costs per km decline over time, though empirical studies suggest this 'rebound effect' is relatively modest (e.g., Gillingham and others 2015).

30 There is a key role for other complementary policies, for example, provision of EV charging infrastructure, procurement for EVs in public vehicle fleets, and (given the large congestion externalities from all vehicles, including EVs) promoting a modal shift to public transportation, (e.g., Ministry of Transport 2020, Jochem and others 2016).

${ }^{31}$ Diesel vehicles directly emit fine particulates (gasoline vehicles do not) and more nitrogen oxide emissions (see Parry and others 2014 for further discussion).

32 This calculation assumes a fuel price elasticity of -0.5 reflecting reductions in vehicle km driven and improvements in fuel efficiency.

33 The lifetime cost of using an average diesel vehicle (based on assumptions used above) would increase about $€ 2,400$. A lower level of tax might be warranted for off-road diesel uses (e.g., farm vehicles, construction) which might be implemented through rebates in business tax regimes.

34 See GON (2019a), section C2.1. A proposal for a national km-based charging system was previously considered in 2009. See https://www.dw.com/en/dutch-approve-per-kilometer-tax-for-drivers/a-4893141-1.
} 


\section{Buildings}

The EU 2020 Climate and Energy Package seeks to reduce energy use in buildings by 32.5 percent by 2030 through construction of nearly zero-energy buildings (NZEB) from 2020 onwards and renovation of the existing building stock. Member states are required to develop their own plans for meeting the EU objectives. In the Netherlands, as in other EU countries, only a small fraction of the building stock currently has a high rating, as defined by Energy Performance Certificates (EPCs), which depend on both the building's energy efficiency and $\mathrm{CO}_{2}$ emissions. $\mathrm{A}$ shift from a low energy efficiency rating ("E" and below), which accounts for 30 percent of the Dutch housing stock, to the highest rating of " $A$ ", which covers 2.5 percent (Figure 18), could reduce energy consumption by about 85 percent on average. To reach the energy efficiency level consistent with the 2030 emission reduction target, the EU-wide renovation rate should be about

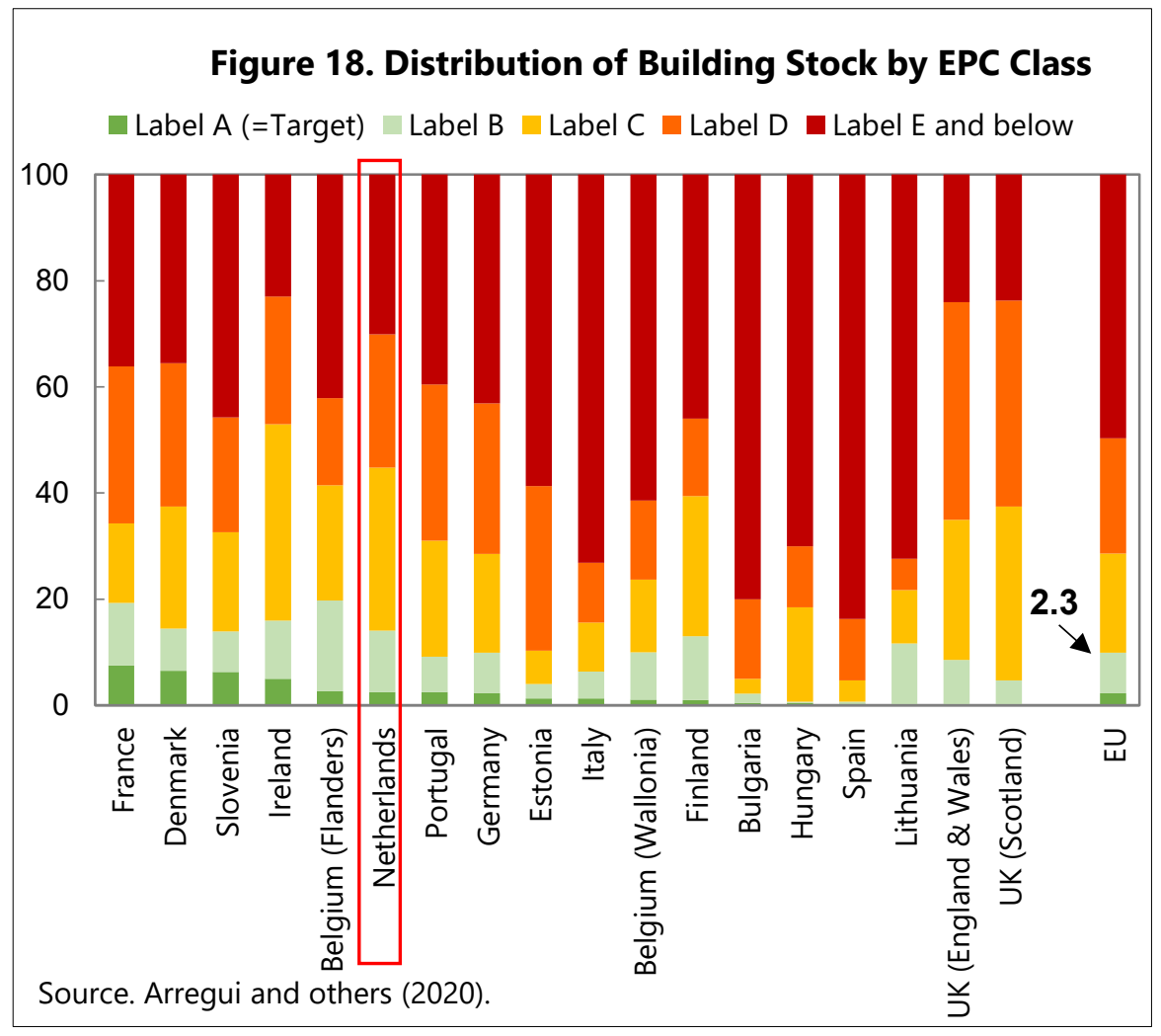
7-8 percent per year. ${ }^{35}$

Increasing the energy efficiency of buildings through better insulation, and cleaner and more efficient heating equipment, is the main channel through which households can reduce emissions from existing buildings. 62 percent of final energy consumption by Dutch households was from space heating in 2019_lighting/electrical appliances, water heating, and cooking accounted for another 18, 17, and 2 percent respectively. ${ }^{36}$ Other energy reduction channels such as energy-efficient lighting and digitalization to "smart" homes (such as optimal automatic adjustment of heating temperatures) and renewable energy-based water heating

\footnotetext{
35 For a detailed discussion, see Arregui and others (2020).

36 Eurostat.
} 
systems can provide further sources of energy savings, but have more limited abatement potential due to their lower energy shares.

Renovation rates may, however, be hindered by possible market failures which would warrant some policy intervention, even when emissions are aggressively priced. ${ }^{37}$ For example, landlords may lack incentives to make energy-saving investments if the savings accrue to their tenants and they are unable to charge a rent premium for more energy efficient housing, while renters themselves may lack investment incentives, especially when their tenancy is short term. ${ }^{38}$ Some households may lack the upfront funds required for major energy-saving investments. And households may be uncertain about the savings in energy consumption from investments, which can be compounded by uncertainty over future energy prices and the quality of contractors for large renovations.

The Dutch government is pursuing several initiatives to cut building sector emissions. These include banning natural gas heating in new constructions, enhancing the energy efficiency of 1.5 million homes (one fifth of the housing stock), efficiency standards for lighting and household appliances, and codes for the design, construction, alteration, and maintenance of buildings.

\section{Various feebate schemes could complement existing measures by strengthening} incentives for energy efficient appliances and buildings. For example, sales of refrigerators, air conditioners, and other energy-consuming products could incur a fee given by:

$$
\begin{aligned}
& \qquad \mathrm{CO}_{2} \text { price } \times \mathrm{CO}_{2} \text { per unit of energy } \\
& \times \text { \{energy consumption per unit }- \text { industry-wide energy consumption per unit }\} \\
& \times \text { number of units }
\end{aligned}
$$

For refrigerators, for example, the energy consumption rate would be kWh per cubic foot cooled (and the number of units would be cubic feet). A similar scheme applying taxes to gas- and oilbased heating systems (for existing buildings), and a subsidy for electric heat pumps, could accelerate the transition to zero-carbon heating systems for pre-existing buildings. Feebate systems linked to EPCs could also be integrated into real estate taxes to encourage energy saving renovations. A variety of other complementary measures are discussed in Annex 2.

\footnotetext{
37 See for example Arregui and others (2020).

3831 percent of the Dutch housing stock was rented in 2018 (Arregui and others, 2020, Figure 15).
} 


\section{Agriculture}

The agriculture sector is a large export contributor for the Netherlands. Although the sector accounts for only 1.5 percent of GDP, net exports of agro-products and horticulture represent almost 4 percent of GDP (Figure 19). In nominal net exports value, the Netherlands is the world's third largest exporter of agro-products in the world, after Brazil and Argentina (Van Grinsven 2019). ${ }^{39}$ It leads globally in exports of potatoes and onions, and ranks second in exports of vegetables overall in terms of value. More than a third of the global trade in vegetable seeds originates in the Netherlands (National Geographic 2019). In 2019, the biggest agricultural exports were ornamental flowers and plants (worth $€ 5.8$ billion), dairy products and eggs (€4.3 billion), meat (€4.0 billion) and vegetables (€3.5 billion). ${ }^{40}$

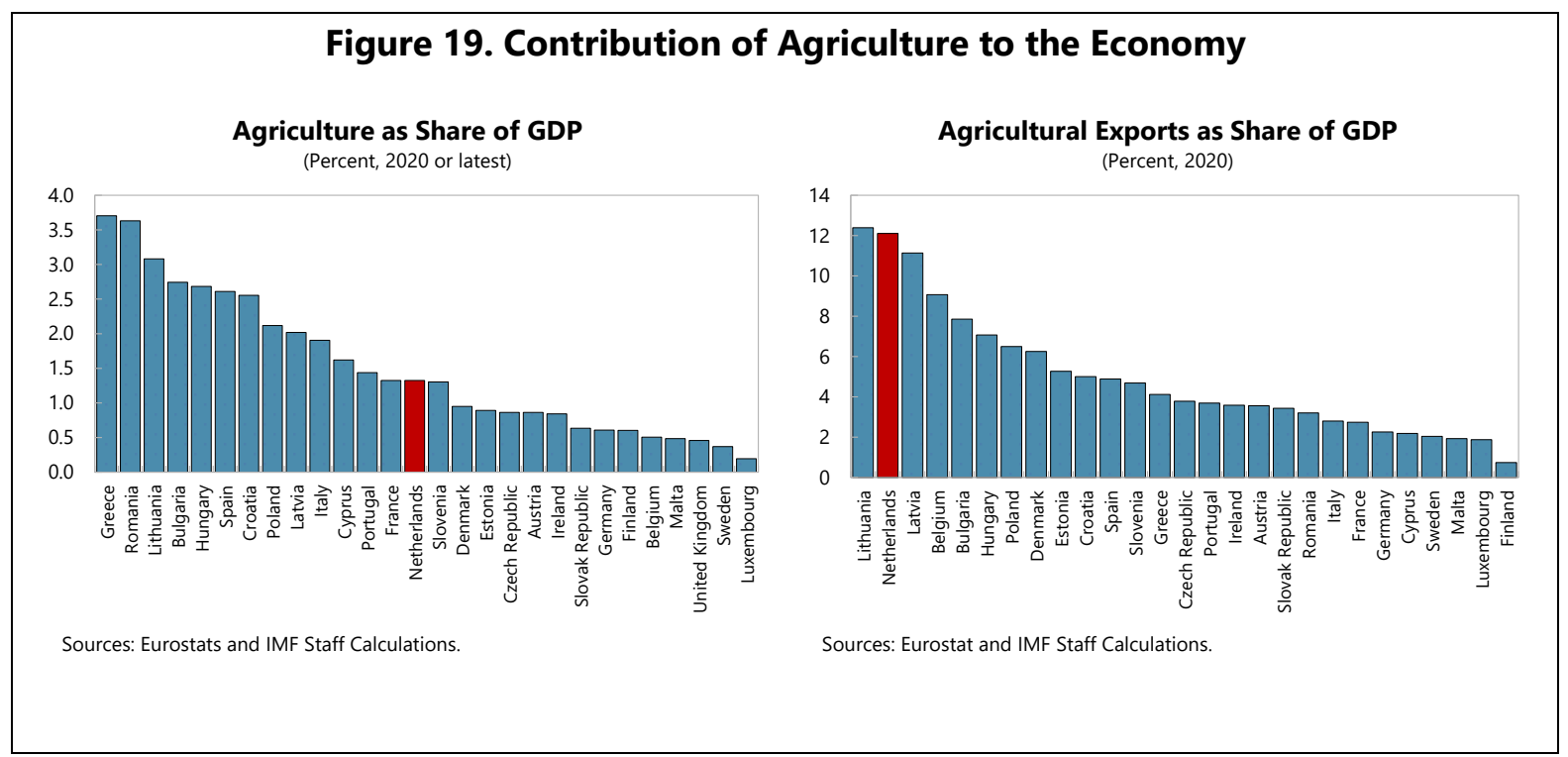

The agricultural sector in the Netherlands is the most productive and efficient in the EU when measured in crop yields per unit of land. The Dutch lead globally in crop yields of tomatoes, cucumbers and chilies and green peppers, and enjoy high yields of pears, carrots, potatoes and onions. All this is achieved with only 0.04 percent of global agricultural land and 1 percent of that in the EU (Van Grinsven 2019). More than half the nation's land area is used for agriculture and horticulture.

\footnotetext{
39 In terms of gross exports, agro-products and horticulture represent almost 12 percent of GDP. This places the Netherlands as the world's second largest food exporter as measured by value, second only to the United States. However, looking at gross exports alone may provide a distorted image as a large share of imported commodities is almost directly re-exported via Rotterdam harbor and Schiphol airport (Van Grinsven 2019).

${ }^{40}$ See https://ecochain.com/knowledge/david-attenborough-dutch-agriculture/
} 
Animal farming is an important part of the Dutch agricultural sector. The Netherlands is the world's fifth largest exporter of dairy products and accounts for over 9 percent of annual milk production in Europe, with a stock of about 1.8 million dairy cows. It is also a large meat producer, with significant herds of pigs $(8.4$ percent of total headcount in Europe), non-diary bovines (2 percent), and poultry $(7.6$ percent). There are more than 1,000 poultry farms in the Netherlands, which together produce 10 billion eggs a year (MacLeod at al, 2013).

Table 4. The Netherlands and the World: Key Agriculture Indicators (data in millions, unless otherwise specified)

\begin{tabular}{|c|c|c|c|c|c|}
\hline & \multicolumn{3}{|c|}{ Stock/volume 2015} & \multicolumn{2}{|c|}{ Share of the Netherlands } \\
\hline & World & EU 28 & Netherlands & World & EU 28 \\
\hline Population & 7,418 & 507 & 17.0 & $0.23 \%$ & $3.35 \%$ \\
\hline Land area (ha) & 12,733 & 423 & 3.38 & $0.03 \%$ & $0.80 \%$ \\
\hline Agricultural land (ha) & 4,775 & 179 & 1.80 & $0.04 \%$ & $1.01 \%$ \\
\hline Cropland (ha) & 1,391 & 119 & 0.81 & $0.06 \%$ & $0.68 \%$ \\
\hline Grassland (ha) & 3,384 & 59 & 0.98 & $0.03 \%$ & $1.66 \%$ \\
\hline Nitrogen use (ha) & 115 & 11 & 0.20 & $0.17 \%$ & $1.77 \%$ \\
\hline Cereal production (t/y) & 2,519 & 317 & 1.62 & $0.06 \%$ & $0.51 \%$ \\
\hline Milk production $(\mathrm{t} / \mathrm{y})$ & 656 & 153 & 14.3 & $2.18 \%$ & $9.34 \%$ \\
\hline Meat production ( $\mathrm{t} / \mathrm{y}$ ) & 307 & 45 & 2.72 & $0.89 \%$ & $6.04 \%$ \\
\hline Cattle & 1,694 & 89 & 4.30 & $0.25 \%$ & $4.83 \%$ \\
\hline Pigs & 977 & 149 & 12.5 & $1.28 \%$ & $8.39 \%$ \\
\hline Poultry & 21,873 & 1,402 & 106.4 & $0.49 \%$ & $7.59 \%$ \\
\hline Sheep and goats & 2,177 & 98 & 1.30 & $0.06 \%$ & $1.33 \%$ \\
\hline
\end{tabular}

The high sectoral productivity translates however into a high carbon and ecological footprint. Overall, non- $\mathrm{CO}_{2}$ (methane, nitrous oxide) emissions per hectare of agricultural land are particularly high in the Netherlands relative to EU peers because of the large herds and the above average use of chemical inputs (see also Van Grinsven 2019). Nitrogen and phosphorus surplus per unit of product for Dutch products often are higher due to the high use of manure (on increase, at 74.6 million tonnes on average per year during 2010-2019 compared to 71 million tonnes per year during 2000-2009), which skews heavily the composition of emissions in the sector. Moreover, extensive greenhouse and animal farming requires reliance on electricity and heating, themselves sectors that contribute to GHG emissions.

Overall, the agriculture sector and land use accounted for about 17 percent of total GHG emissions in the country in 2019, or $\mathbf{3 1 . 2} \mathrm{Mt} \mathrm{CO}_{2 \mathrm{e}}$. According to Eurostat data, the Netherland's share of GHGs from crop and animal agriculture in total GHGs in 2019 was slightly below the average in other EU countries (top left chart, Figure 18). These emissions have hardly decreased since 2000. Per capita nitrogen emissions are four times the EU average, with an estimated 61 percent coming from agriculture. ${ }^{41}$ In the current bid to meet climate mitigation commitments, the agricultural sector will need to reduce emission by $3.5 \mathrm{Mt} \mathrm{CO}_{2}$ in 2030 . The relative reduction target for GHG by agriculture is 11 percent and less than the national target of 49 percent, but it is still a challenge because the technical potential for reduction of methane and nitrous oxides is relatively small. Crop production, animal farming, food waste, and heating and electricity of greenhouses contribute to GHG in agriculture (Box 2).

\footnotetext{
41 See https://www.reuters.com/article/us-netherlands-construction/netherlands-cuts-speed-limit-to-reducenitrogen-pollution-idUSKBN1XN13K
} 
Crop cultivation contributes 29 percent of the Dutch agricultural GHG (bottom left chart, Figure 20). ${ }^{42}$ The main source are the nitrous oxide emissions from the use of mineral fertilizers and from manure storage and spreading on croplands. Pesticides/herbicides and fertilizers are chemical and destroy the soil and biodiversity, grossly reducing carbon capture for decades if not centuries. In the Netherlands, most products are obtained through conventional farming. Only 1.5 percent of total utilized agricultural area is devoted to organic farming, compared to an average of more than 3 percent in EU28 according to Eurostat. Reflecting this, only about 2,000 of the 50,000 Dutch farming companies are classified as organic. ${ }^{43}$

Livestock production accounts for $\mathbf{7 1}$ percent of the Dutch agricultural GHG (bottom left chart, Figure 20). Most livestock emissions have as main sources: methane emissions from the enteric fermentation of ruminants such as cows and sheep, the decomposition of manure under anaerobic conditions, and feedstuff production. Ruminants contribute directly to greenhouse gas emissions by burping methane as they digest their food (estimated at 46 percent of total agricultural emissions in the Netherlands). Manure produces ammonia, a form of nitrogen emissions which has harmful effects on soil, water and biodiversity, and also reacts to form nitrous oxide, a greenhouse gas. While lower than in the mid-90s, nitrogen emissions from livestock manure have remained large (bottom right chart, Figure 20) - a direct effect of the large increase in livestock herd and pigs, which has grown since 2015 especially dairy (Figure 21), which makes the Netherlands show the highest livestock density per unit of utilized agricultural area in Europe (top right chart, Figure 20). Livestock manure management accounts for almost 25 percent of the total emissions from agriculture, significantly above the EU-28 average of 15 percent. A third source of emissions in animal farming is the feedstuff for livestock. For example, about three-quarters of poultry emissions come from feed production (MacLeod at al, 2013).

The government recognizes that a successful national emissions mitigation strategy must include measures to reduce emissions from farming and livestock. In this spirit, the 2019 Climate Agreement envisages policies for sustainable heating in greenhouse horticulture (discouraging natural gas consumption through pricing), reducing methane emissions from livestock through improved processing of manure, implementing carbon storage in soil and vegetation through pilot programs for climate-friendly land use, and adopting incentives for climate-friendly food consumption and food waste reduction. Dutch farmers have also almost completely eliminated the use of chemical pesticides on plants in greenhouses (National Geographic 2019). Reducing herds size is however very controversial and difficult. For example, when in May 2019 the Netherlands breached its strict legal cap on nitrogen emissions, the government was forced to look for interventions outside agriculture to address the problem,

\footnotetext{
42 Shares calculated using Eurostat/EEA data. In 2018, the agriculture sector generated a total of 18.2 Mtonnes CO2-e (excluding LULCF).

43 See https://www.dutchnews.nl/news/2020/01/more-farmland-goes-organic-but-the-netherlands-still-trails-ineurope/; https://www.skal.nl/en/biologisch
} 
notably stopping construction projects and cutting the motorway speed limit to curb emissions ${ }^{44}$.

Given the larger than average role of agriculture in emissions, the climate change mitigation goals for the sector could be made more ambitious. The target for agricultural GHG emissions could be raised from 25 percent by 2030, as currently projected, to 49 percent in line with the emissions mitigation pledge for the whole economy. The 2019 Climate Agreement envisages a reduction of $2.7 \mathrm{Mt} \mathrm{CO}_{2 e}$ but the authorities could go much further with bolder polices. Moreover, the levers for mitigation in 2019 Climate Agreement remain uncertain and risky for the success of the overall strategy. For example, more could be done to reduce GHGs emissions from animal agriculture. While the 2019 Climate Agreement refers, among others, to scaling back pig farming, the targets remain unclear. There is also no clear guidance on the number of cattle and pigs, and neither to changes to the chemical approach to industrial factory farming. Some of the considerations to keep in view when discussing the role of agriculture in reducing emissions include:

- Reducing the stock of animals raised. Apart from technical measures and innovations, there is an increasing call in society for structural measures, such as the reduction of livestock, to ensure an appropriate reduction of GHG emission from agriculture. Reducing livestock by half (Batini and Pointereau 2021) would support efforts to abate consumption of such products in the Netherlands and abroad. Concerns about leakage effects if livestock production simply moves elsewhere, particularly in the EU, would need to be addressed.

- Increasing the share of land farmed organically. The high contribution of nitrogen fertilizers to GHG suggests that the Netherlands should significantly increase the share of organic (no chemical input) and regenerative (no chemical input and ecosystem restoring) farming. This would require both setting an ambitious goal and designing a strategy to attain it.

- Moving to sustainable diets. Consumers need to be incentivized to materially change their behavior, including by reducing animal protein (mostly beef and lamb) consumption and food waste. Making diets sustainable is key to validate a reduction in production.

- Making greenhouse farms energetically net zero (sustainable).

\footnotetext{
44 See https://www.ft.com/content/088e0ecc-51a6-11ea-a1ef-da1721a0541e
} 
Figure 20. Agriculture and GHG Emissions

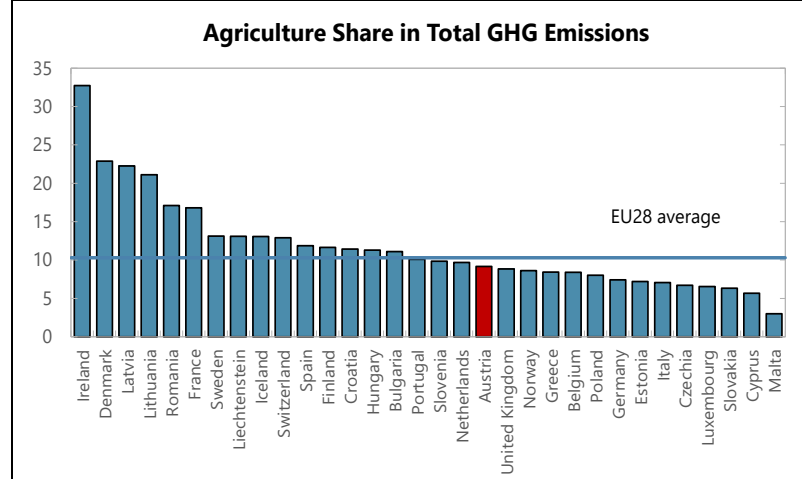

Source: Eurostat, IMF staff calculations

Decomposition of Greenhouse Gas Emmissions in Agriculture (2018)

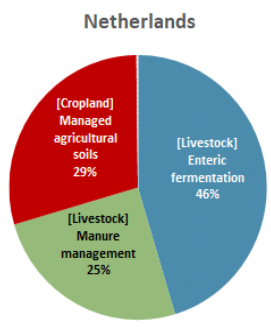

Source: Eurostat, European Environment Agency, IMF staff calculations
EU+UK: Agriculture — Livestock Density and Total Emissions, $2015^{1}$

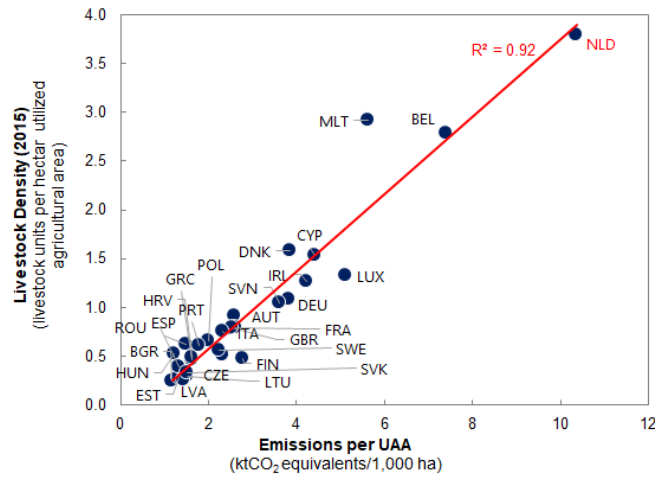

Sources: Arregui and others (2020) using European Environment Agency data

1 Emissions from agricultural transport and energy use are excluded, as are emissions/removals 1 Emissions from agricultural transport and energy use are excluded, as are emiss
from LULUCF, cultivation, field burning of agricultural residues and other sources.

Netherlands: Livestock Manure and Emissions (million kilograms)

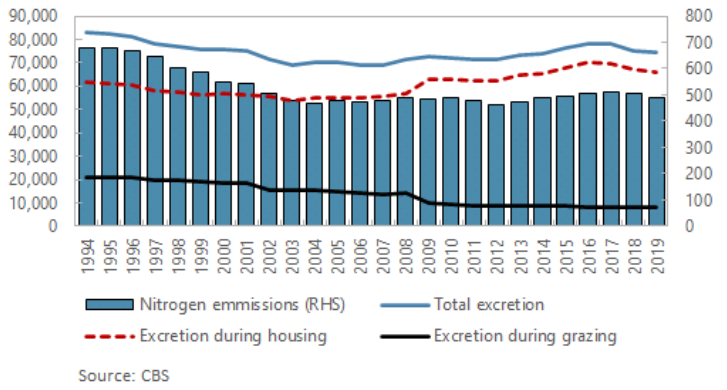

Figure 21. The Netherlands: Composition of Livestock

Grazing Livestock

(millions)

Source: CBS

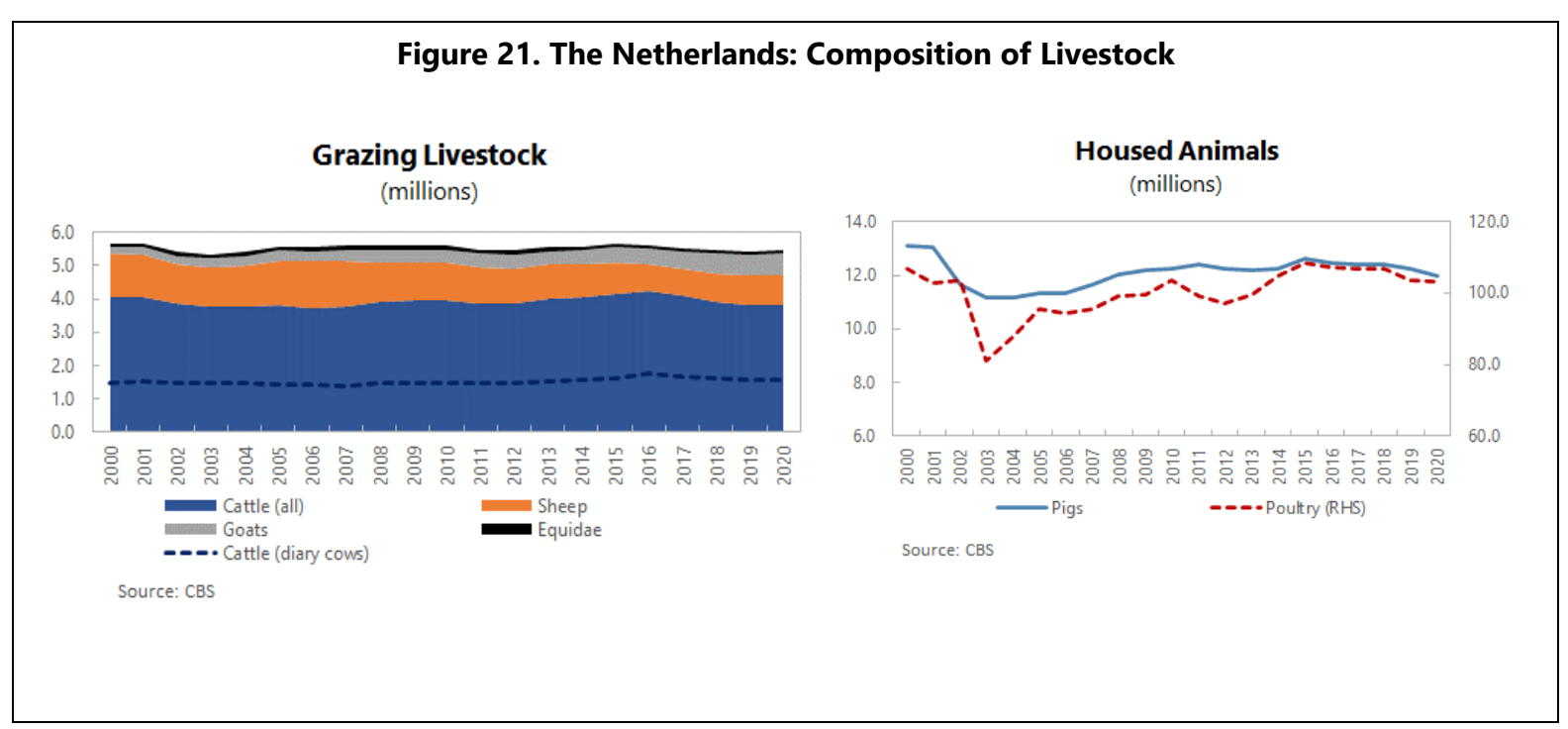

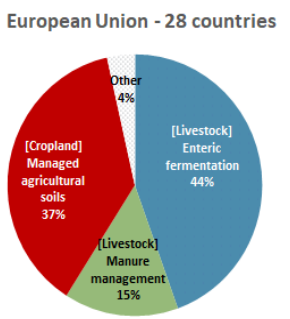

Source: CBS 


\section{Box 2. Sources of Agricultural GHG Emissions in the Netherlands 1/}

The GHG emissions reflect four main factors:

- Most crop production utilizes synthetic fertilizers and pesticides (practices with high environmental impacts). The Netherlands has the highest consumption in the EU of nitrogen fertilizer, a chemical which is an important source of GHGs and soil degradation.

- Animal farming is highly industrialized. Livestock density per utilized agricultural area in the Netherlands is the highest in the EU) and focused on emissions-intensive cattle and pigs production in the last decade. Cows release methane (a potent GHG) through enteric fermentation, as do pigs (albeit in smaller proportions), while management of their waste produces large amounts of nitrous oxide. ${ }^{2}$ In 2019, the total number of cattle and pigs in the Netherlands exceeded 3.8 million and 11.9 million respectively $(0.2$ cows and 0.7 pigs for every Dutch citizen), while the stock of sheep and goats is around 1.5 million. ${ }^{3}$ These animals produce $12.6 \mathrm{Mt} \mathrm{CO}_{2}$-eq

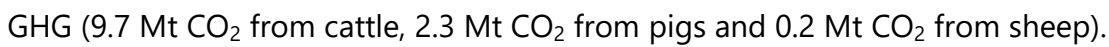

- Food waste, albeit more limited per capita than elsewhere in the EU, also contributes to GHG emissions. About EUR 2.4 billion worth of edible food, or 8-11 percent of the food Dutch consumers buy, is thrown away ${ }^{4}$, implying that significant amounts of $\mathrm{CO}_{2 \mathrm{e}}$ are wasted or lost a year.

\section{- Heating and electricity of greenhouses.}

1/ This box draws on Batini et all 2020

1 More specifically, the nitrogen $(N)$ fertilizer consumption per hectare of fertilized utilized agricultural area (UAA) in the Netherlands in 2018 corresponded to $120 \mathrm{~kg} / \mathrm{ha}$ vs. $77.2 \mathrm{~kg} / \mathrm{ha}$ in the EU-28 (Eurostat, 2020)

2 Batini (2019), Batini and Pointereau (2021). Methane and nitrous oxide have Global Warming Potential (GWP) of 28-36 and 265-298 that of carbon dioxide respectively, over a 100-year timescale - the GWP being a measure of how much energy the emissions of 1 tonne of a gas will absorb over a given period of time, relative to the emissions of 1 tonne of $C_{2}$ (EPA 2021). And much higher still over a shorter timespan implying immediate reductions in the Netherlands' contributions to global warming, contrary to cuts to the use of fossil fuels which have a more delayed impact on global warming given the phenomenon of "committed warming" (Batini and Pointereau, 2021).

3 CBS Open Data (2021).

4 FAO (2010).

\section{Specific policy measures to support these broad objectives need to target both production} and consumption activities. Production-side measures are especially important in light of the substantive portion of output bound for the export market, and consumer-side measures can play a useful complementary role.

- At the production level, a feebate approach, charging farmers for the difference between their $\mathrm{CO}_{2 \mathrm{e}}$ emissions per hectare and the industry average per hectare, may be more acceptable than a tax on (estimated) emissions. The latter imposes a new tax burden on all farmers and 
poses greater risks of emissions leakage. Temporary subsidies could also be targeted to increase the share of organic farming and fiscal incentives used to repurpose (mainly livestock) farms toward polyculture farming.

- At the consumer level, fiscal schemes that raise the relative price of beef, pork and dairy products relative to plant-based food would improve incentives, while also promising significant health benefits from improved nutrition. Lowering consumption of animal products would also help contain the risk of emission leakage cause by differences in international taxation of high-externality foods. Structural reforms to foster a transition toward sustainable agriculture like regenerative and organic farming can reinforce and accelerate the impact of proposed changes in tax and subsidy policies.

\section{Conclusion}

The Netherlands' existing GHG reduction targets and the likely new EU-wide target call for an acceleration in decarbonization. The Netherlands has made progress in reducing GHGs since 1990 (by 17 percent already) and has ambitious reduction targets for the future - to cut them by 49 percent below 1990 levels by 2030 and 95 percent by 2050. As of 2019, most reductions have been made in industry, buildings, and agriculture, but much more needs to be done across the board, and in the power sector.

\section{A comprehensive strategy and more robust carbon pricing are needed to achieve} Netherland's GHG reduction targets. The government has put forward a broad range of measures, which along with the operation of the ETS, are expected to deliver significant emissions reductions this decade. However, even with these policies, including those still in the pipeline, emission reductions are expected to fall short of the national targets. This paper has presented a variety of measures for consideration to strengthen the current policy framework and help the Netherlands fully achieve its targets. For industry, it recommends modifying the recently introduced carbon levy into a revenue-neutral feebate. For power generation, it recommends eliminating taxes on residential and industrial electricity and supplementing the coal phaseout plan by raising the $\mathrm{CO}_{2}$ emissions floor price to $€ 160$ by 2030 . A more aggressive subsidization of renewables would also need to be considered in light of the plan to extend the coverage of renewables to 70 percent of energy production. The vehicle excise tax system could be modified to include a feebate and applying feebates to the building sector will help promote energy efficiency and clean technologies. In agriculture, it recommends applying feebates to livestock and crop production, reducing herd concentration, and incentivizing a transition to organic/regenerative farming and more plant-based diets.

\section{These reforms should have a limited impact on consumption and administration. On} consumption, the impact would be low and relatively evenly split across the income distribution. The administrative and operational changes to implement the feebate system should also be 
straightforward, at least in the main energy sectors. For example, a pure feebate is easily integrated in vehicle registration tax systems. For industry, the feebate is a modest variant of the carbon levy with earmarking of the proceeds to fund other climate mitigation actions. Although the carbon levy permits additional degrees of freedom in deciding how the proceeds are to be used, the feebate has the advantage of strengthening incentives for abatement among all participants in the industry. For power generators, the fees/rebates could be applied on the average emission rates at the same time as EU ETS permits are surrendered.

\section{References}

Arregui, Nicolas, Ruo Chen, Christian Ebeke, Jan-Martin Frie, Daniel Garcia-Macia, Dora lakova, Andy Jobst, Louise Rabier, James Roaf, Anna Shabunina, and Sebastian Weber, 2020. Sectoral Policies for Climate Change Mitigation in the EU. Departmental Paper, International Monetary Fund, Washington, DC.

Batini, Nicoletta and Philippe Pointereau, 2021. Greening Food Supply in Advanced Economies, in "The Economics of Sustainable Food: Smart Policies for Health and the Planet", Batini, Nicoletta (ed.). Island Press and International Monetary Fund.

Batini, Nicoletta, 2019. Macroeconomic Gains from Reforming the Agri-Food Sector: The Case of France". International Monetary Fund WP No. 19/41 (Washington: International Monetary Fund). Available at: https://www.imf.org/en/Publications/WP/Issues/2019/02/26/Macroeconomic-GainsfromReforming-the-Agri-Food-Sector-The-Case-of-France-46583

Batini, Nicoletta, lan Parry, and Philippe Wingender, 2020. Climate Mitigation Policy in Denmark: A Prototype for Other Countries, International Monetary Fund WP No. 2020/235 (Washington: International Monetary Fund). Available at: https://www.imf.org/en/Publications/WP/Issues/2020/11/12/Climate-Mitigation-Policyin-Denmark-A-Prototype-for-Other-Countries-49882

Bird, Stephen and Diana Hernández, 2012. Policy Options for the Split Incentive: Increasing Energy Efficiency for Low-income Renters, Energy Policy 48: 506-514.

Chen, Jiaqian, Maksym Chepeliev, Daniel Garcia-Macia, Dora lakova, James Roaf, Anna Shabunina, Dominique van der Mensbrugghe, and Philippe Wingender, 2020. EU Climate Mitigation Policy. Departmental Paper, International Monetary Fund, Washington, DC.

Dodge Data and Analytics, 2018. World Green Building Trends 2018. SmartMarket Report, Bedford, MA. 
EPA, 2021. Understanding Global Warming Potentials, United States Environmental Protection Agency. Available at: https://www.epa.gov/ghgemissions/understanding-globalwarming-potentials

Eurostat, 2020. Agri-environmental indicator - mineral fertiliser consumption https://ec.europa.eu/eurostat/statistics-explained/index.php?title=Agrienvironmental indicator - mineral fertiliser consumption\#Analysis at EU level

Flachsland, Christian, Michael Pahle, Dallas Burtraw, Ottmar Edenhofer, Milan Elkerbout, Carolyn Fischer, Oliver Tietjen and Lars Zetterberg, 2018. Five myths about an EU ETS carbon price floor, CEPS, Policy Insights, No. 2018/17. Available at: http://aei.pitt.edu/95835/1/EU ETS Carbon Price Floor Myths and enlightenment final.p $\underline{\mathrm{df}}$

FAO (2010). Fact Sheet: Food Waste in the Netherlands. Dutch Ministry of Agriculture, Nature and Food Quality. Available at: http://www.fao.org/fileadmin/user upload/nr/sustainability pathways/docs/4 Fact\%20Sh eet\%20Food\%20Waste\%20in\%20the\%20Netherlands.pdf

Gillingham, Kenneth, David Rapson, and Gernot Wagner, 2015. The Rebound Effect and Energy Efficiency Policy, Review of Environmental Economics and Policy 10: 68-88.

GON, 2019a. Climate Agreement. Government of the Netherlands.

GON, 2019b. Climate deal makes halving carbon emissions feasible and affordable. Government of the Netherlands. Available at: www.government.nl/latest/news/2019/06/28/climate-dealmakes-halving-carbon-emissions-feasible-and-affordable.

IEA, 2020. Energy Prices and Taxes for OECD Countries 2020. International Energy Agency, Paris.

IMF, 2019a. Fiscal Monitor: How to Mitigate Climate Change. International Monetary Fund, Washington, DC.

IMF, 2019b. Fiscal Policies for Paris Climate Strategies_From Principle to Practice. International Monetary Fund, Washington, DC.

Jochem, Patrick, Claus Doll, and Wolf Fichtner, 2016. External Costs of Electric Vehicles. Transportation Research Part D: Transport and Environment 42: 60-76.

Keen, Michael, Ian Parry, James Roaf, and Simon Black, 2021. "Border Carbon Adjustments: An Economic Perspective." Working paper, International Monetary Fund, Washington DC, forthcoming. 
MacLeod, M., Gerber, P., Mottet, A., Tempio, G., Falcucci, A., Opio, C., Vellinga, T., Henderson, B. \& Steinfeld, H., 2013. Greenhouse gas emissions from pig and chicken supply chains $-A$ global life cycle assessment. Food and Agriculture Organization of the United Nations (FAO), Rome. Available online at http://www.fao.org/3/i3460e/i3460e.pdf

Ministry of Transport Building and Housing, 2020. Report of the Working Group on Fossil Free Transport. Helsinki, Finland

OECD, 2019. Taxing Energy Use 2019: Using Taxes for Climate Action. Organization for Economic Cooperation and Development, Paris, France.

Parry, Ian W.H., 2004. Comparing Alternative Policies to Reduce Traffic Accidents, Journal of Urban Economics 56: 346-368.

Parry, Ian, Dirk Heine, Shanjun Li, and Eliza Lis, 2014. Getting Energy Prices Right: From Principle to Practice. IMF, Washington DC.

PBL Netherlands Environmental Assessment Agency, TNO Energy Transition, Statistics Netherlands (CBS), and the National Institute for Public Health and the Environment (RIVM), 2020. Netherlands Climate and Energy Outlook 2020. Available at: https://www.pbl.nl/en/publications/netherlands-climate-and-energy-outlook-2020summary

UNEP, 2020. Emissions Gap Report 2020. UN Environnent Programme, Nairobi, Kenya.

Van Grinsven Hans J. M., van Eerdt Martha M., Westhoek Henk, Kruitwagen Sonja, 2019. Benchmarking Eco-Efficiency and Footprints of Dutch Agriculture in European Context and Implications for Policies for Climate and Environment, in "Frontiers in Sustainable Food Systems", Vol 3, pp 13. Available online at: https://www.frontiersin.org/articles/10.3389/fsufs.2019.00013/full

Viviano, Franck, 2017. This Tiny Country Feeds the World: Agricultural Giant Holland is Changing the Way We Farm, National Geographic Magazine. Available online at: https://www.nationalgeographic.com/magazine/2017/09/holland-agriculturesustainable-farming/

WBG, 2021. Carbon Pricing Dashboard. World Bank Group, Washington, DC. Available at: https://carbonpricingdashboard.worldbank.org/map data. 


\section{Annex I. Broader Reforms to the Pricing of Road Transportation}

Traffic congestion imposes large external costs on road users. Congestion is excessive because motorists do not account for their impact on slowing road speeds for other road users. Average drivers in Amsterdam, Eindhoven, the Hague, Rotterdam, and Utrecht lose between 70 and 95 hours per year stuck in traffic jams. ${ }^{45}$

Congestion can be efficiently managed (for given road capacity) through $\mathbf{k m}$-based taxes varying by location and time of day. Per km tolls on busy roads that progressively rise and fall over the rush hour exploit all behavioral responses for reducing congestion (e.g., setting off before or after the peak of the rush hour; shifting to off-peak travel, less congested roads, or public transportation; carpooling; reducing trip frequency). Developments in metering technologies such as global positioning systems imply that people's driving could be tracked and billed accordingly. ${ }^{46} \mathrm{~km}$-based charging might be promoted through subsidizing/taxing vehicles with/without monitoring capacity during a transition period with monitoring capacity eventually becoming mandatory. Unlike fuel taxes, $\mathrm{km}$-based taxes provide a robust general revenue base which would be unaffected by decarbonization of transportation and is especially valuable given fiscal pressures from the COVID-19 crisis.

Transitioning from lump-sum to pay-as-you-drive (PAYD) automobile insurance, under which premiums vary in proportion to the policyholder's annual $\mathbf{k m}$, would further reduce driving and help to internalize traffic accident externalities. Motorists do not account for various accident risks to others posed by their own driving (e.g., injury risks to pedestrians and to other vehicle occupants in multi-vehicle collisions, third-party property and medical costs) (see Parry 2004). Existing rating factors, as determined by insurance companies, could be used to set per km charges for different drivers as an (albeit imperfect) proxy for external accident risk: drivers with prior crash records, for example, would pay higher variable charges and would have the greatest incentives to drive less. The transition to PAYD could occur on a voluntary basis, with the government kickstarting the process using tax incentives. ${ }^{47}$ Drivers with below-average annual km would have the strongest incentives to take up PAYD and as they switched, premiums would rise for the remaining pool of drivers with lump-sum insurance, encouraging further shifting to PAYD. On average, PAYD would raise the marginal cost of driving by around 4 cents per $\mathrm{km}$ (while reducing the average accident risk for all drivers). ${ }^{48}$

45 See www.statista.com/statistics/990532/hours-spent-in-traffic-jams-in-the-netherlands-per-city.

46 The administrative costs would however be higher than for collecting fuel taxes, due to the need to charge individuals rather than fuel distributors. An alternative, bottom-up approach would be to progressively expand congestion-charging zones (e.g., in London), though this would be far less comprehensive than a nationwide charging system.

${ }^{47}$ Government incentives may be needed to overcome obstacles to the private development of PAYD. When an insurer charges by the $\mathrm{km}$, its costs are reduced to the extent that its own customers reduce their accident risk by driving less. However, the costs to other insurance companies also are lowered because the risk of multi-car accidents for their own customers is lower, but savings cannot be captured by the company offering the kmbased insurance.

${ }^{48}$ Assuming an annual insurance payment of $€ 500$ and $11,450 \mathrm{~km}$ driven per year. 
Annex II. Complementary Measures for Reducing Building Emissions

Further options include: ${ }^{49}$

Set binding targets for energy efficiency renovations to establish a clear path towards a low-emission building stock.

Increase availability and commercial relevance of building efficiency information. Ensure that the requirement for EPCs when a building is sold or rented is strictly enforced and expand current disclosure obligations to any bank lending collateralized by real estate; establish incentives for inspection schemes for heating and air conditioning systems (possibly supported by tax incentives).

Expand options for "on-bill" financing of energy efficiency investments. The amortization of investment cost through future energy bills shifts repayment to the occupant (and energy user) rather than the owner of a building. It can help overcome the investor-user barrier by raising incentives for both landlords and homeowners with limited planned ownership-tenure to undertake investments. ${ }^{50}$

Enhance financial support through "green mortgages". Increase funding and support for renovation - by mobilizing public and private financing and investment and strengthening long-term building renovation strategies; legislating the definition of energy efficient mortgages; and offering means-tested low-interest loans or grants for renovation.

Remove structural constraints. Introduce certification and training programs for developers/contractors; amend vocational training in skill areas essential to energy-efficient renovation to prevent supply shortages. The challenge is to expand and restructure the supply side to create an industrial sector that can provide retrofitting solutions that are understandable for owners and tenants and that can sustain high rates of retrofitting. This includes factors such as the provision of a skilled workforce, cooperation between different trades, and the creation of certifications and advisory structures.

Raise greater awareness of energy efficiency benefits. Awareness campaigns (e.g., including information on energy usage of comparable houses of higher energy standards and associated savings in the energy bill) have the potential to increase energy saving investments at relatively low cost.

Ensure inclusive transition via supportive policies. Combat energy poverty by providing means-tested grants to vulnerable households to reduce their energy bills and support the renovation and improved energy performance of older buildings, with a focus on social housing.

49 These options are taken from Arregui and others (2020).

50 This "on-bill financing" practice is followed in some parts of the United States (e.g., Bird and Hernandez, 2012). 